\title{
Microplastics pollution studies in India: a recent review of sources, abundances and research perspectives - a comparison with global research
}

Karthikeyan Perumal ( $\sim$ pkarthikeyangold@gmail.com)

Alagappa University https://orcid.org/0000-0002-8782-4146

Subagunasekar Muthuramalingam

The Gandhigram Rural Institute Deemed University

Research Article

Keywords: Microplastics, biota, sea salt, beaches, islands, estuaries, sediments, India

Posted Date: March 7th, 2022

DOI: https://doi.org/10.21203/rs.3.rs-535083/v2

License: (c) (i) This work is licensed under a Creative Commons Attribution 4.0 International License. Read Full License 


\section{Abstract}

Microplastics (MPs) are ubiquitous, persistent pollutants reported in abundance in all environments and biota. The main objective of this review is to identify the sources, distribution, and concentration of microplastics in all aquatic environments and biota in India. It is one of the least studied, with only 45 papers published on microplastics during 2013-2020 in the web of science. To define the concentration of microplastics in different aquatic environments such as 3096 items $/ \mathrm{kg}$ in marine sediments, $106 \mathrm{items} / \mathrm{kg}$ in biota, 59 items/L in seawater, 175 items $/ \mathrm{kg}$ in sea salt, $33.9 \mathrm{items} / \mathrm{L}$ in lake water, $336 \mathrm{items} / \mathrm{kg}$ in lake sediments, 288 pieces $/ \mathrm{m}^{3}$ in river water, and 328 items $/ \mathrm{kg}$ in river sediments. Hence we investigated MPs pollution in coastal and freshwater ecosystems such as rivers, lakes, and biota. However, knowing that many aquatic habitats and species were unexplored, we recommend extending investigations in all of the following areas. To reduce plastic consumption and its eventual threat to aquatic ecosystems, researchers should assess studies in each of these ways. Enforcing severe regulations, enhancing legal activities, well-planned comprehensive waste management plans, and spontaneous public engagement are also required to prevent land-based plastic pollution.

\section{Introduction}

[1] was the first to coin the term "microplastics" to express the small-sized $(<5 \mathrm{~mm})$ plastic particles in the oceans. Most results have been released on this matter globally. Environmental plastic debris is defined by solid-state, solubility, chemical composition, shape, size, color, and origin. Based on the dimension, plastics are graded as nano $(1000 \mathrm{~nm})$, micro $(1000 \mathrm{~mm})$, meso $(10 \mathrm{~mm})$, and macro $(1 \mathrm{~cm})$ [2]. Microplastic consists of primary microplastics manufactured in microscopic size for particular purposes (microbeads) and secondary microplastics derived from huge plastic debris degraded and fragmented by long-term chemical, physical, and biological environmental effects $[3,4]$.

Plastics became prominent a few years ago due to their resilience and functional affordability; however, plastic production rose from $15 \mathrm{Mt}$ (1964) to $311 \mathrm{Mt}$ (2014) and is predicted to double by the next twenty years. Unless the current increase in the manufacture and usage of plastic continues, by 2050, we will have far more plastics occupied in the ocean than fish [5]. Small types of plastic, commonly recognized as microplastic, are far more common as it is highly volatile due to their small size and can reach food chains and different ecosystems. Fishing contributes to microplastic pollution. Modern techniques in fisheries need plastics due to various advantages over conventional natural resources. Accidental loss, natural wear and tear of fishing products, and ancillary items such as gear ropes, nets, strapping bands, fish boxes, etc., tend to leave many plastic fibers and pieces [6]. Tourism and recreational activities mainly have single-use plastics in coastal areas, contributing to coastal microplastics [7]. Numerous studies on the toxicological impact of microplastic particles on several fish are accessible [8-15]. Reviews latest studies on the harmful consequences of fishes micro - and nano plastics ingestion [8]. In 1972, tiny plastic particles on the Sargasso Sea surface [16], many researchers have researched microplastics due to their harmful effects on the aquatic environment. Microplastics are identified in rivers, streams, oceans, the atmosphere, biota ecosystems, and aquatic ecosystems worldwide [17-55]. Microplastics were detected in marine biota in different parts of India [56-66]. Microplastics (MPs) are profuse in the marine environment, including marine sediments, beach, and seawater [67-91]; MPs in sea salt [92-94]; MPs in Island [95-97]; in riverine systems [98-99]; microplastic in lake water and sediments [100-101].

Twenty-five review papers were published related to microplastic in marine environments during 2010-2020. Research on microplastics using bibliometrics analysis [102], microplastic pollution in sedimentary marine environments [4, 103-111], microplastics and their ecotoxicological effects on biota [112-116], physical and chemical characteristics of microplastics [117-118] sampling, and analytical techniques of microplastics [119-124], Action plan for extenuating land-based plastic marine pollution [125].

The present review aims (i) to emphasize the findings on the concentration of microplastic in marine sediments, beach sand, seawater, sea salts, freshwater lake, riverine, and biota. (ii) Sources, identification, composition, and their distribution used in India, possibly one of the least studied with only forty-five papers published on microplastics during 2013-2020 in the Web of Science. (iii) to examine the characteristics of publication results, the distribution of subject grouping, and journals. (iv) to highlight the spatial distribution of microplastic in all aquatic environments and comparison with global research. (v) to discuss India's National marine litter policy and identify the research gaps to steer future research findings.

\section{Methodology}

\section{Data sources and search criteria}

In Scopus and Web of Science database, a systematic literature search was undertaken using a variety of keywords like "microplastic studies in India" OR "microplastics in biota" OR "plastic debris in marine environments" OR "microplastic in marine sediments" OR

Page $2 / 30$ 
"microplastic in beach sand" OR "microplastic in sea salt". The retrieved articles are screened, and only such microplastics works were chosen. It has resulted in 45 research articles published from 2013 to 2020, and these are taken up for detailed review. According to the following research topics, the articles are categorized into i) analytical methodologies, identifications, compositions, and distribution of microplastics used in India, which is one of the least studied with only forty-five papers published on microplastics during $2013-2020$ are identified in the web of science (Fig. 1). Statistics indicate that the amount of MPs studies publications has grown steadily in the last five years.

\section{Results And Discussion}

\section{Sources of microplastics}

Microplastics differ in size, specific density, chemical composition, and shape [126]. They are present in day-to-day products such as cosmetics, paints, etc. (primary microplastics) or from the degradation of larger macroplastic debris by environmental factors (secondary microplastics) $[111,127,128]$ (Fig.2). Microplastics are plastics with a diameter of less than 5 mm, a relatively significant component of this anthropogenic waste. These plastics can enter the environment in two forms: primary microplastics, which are manufactured to size, and secondary microplastics, formed when larger plastic particles break down [129]. Primary microplastics are manufactured for various domestic and industrial purposes. They are used in facial cleansers, hair coloring items, insect repellents, toothpaste, abrasives, synthetic clothing, cleaning products $[4,128,130-133]$. These products are described as open use products as they are washed off and drained in the environment [132]. Chang identified polyethylene beads used in facial cleansers varying from 60 to $800 \mu \mathrm{m}$ and reported that roughly $5000 \mathrm{~g}$ of microplastics were drained annually in the waste stream. Secondary microplastics are formed when larger plastic debris at sea and land subjected to physical, chemical, and biological processes decreases the structural stability of macroplastic debris, resulting in fragmentation [4]. The fragmentation process is more active on beaches due to the presence of high UV light (photo-degradation), physical wave abrasion, supply of oxygen [4,134], and turbulence [135]. If these fragments reach surface waters or deep habitats, colder temperatures and decreased UV light slow down the breakdown process [134]. The degradation persists until the particles become smaller and microplastic in scale [4, 135]. It is reported that about 245 tonnes of microplastics are generated per year, which ends up in water sources where they are absorbed and ingested by marine organisms $[137,138]$. The mechanisms of fragmentation and degradation are essential in forming secondary microplastics, although they are incompletely defined. Microplastics have been found littering the environment at all stages of the plastic life cycle of the product, from producers to waste management. Microplastics can enter the marine environment through river systems, coastlines, ships, and platforms at sea, or wind-induced transfer in the atmosphere.

\section{Waste Water Treatment Plants (WWTPs)}

Significant microplastics are found in discharges from wastewater treatment plants (WWTPs), and most are released into the rivers. The principal purpose for WWTPs is to handle wastewater; however, they add a bulk amount of microplastics into the marine environment due to their improper disposal $[139,140]$. In tertiary treatment, full recovery was reached, which was not expected when secondary treatment was used. Although most WWTPs use only secondary treatment, tertiary treatment performs better. Even then, tertiary treatment eliminates only $99.2 \%$ of microplastics.

\section{Publication data}

The original research articles in Marine Pollution Bulletin (40.74\%), Science of the Total Environment (18.52\%), Environmental Science and Pollution Research (7.41\%), Chemosphere (5.56\%), Environmental Pollution (5.56\%), Environmental Geochemistry and Health (3.70\%), Environmental Monitoring and Assessment (3.7\%), Archives of Environmental Contamination and Toxicology, Journal of Cleaner Production, Environmental Forensics, Regional Studies in Marine Science, Journal of Environmental Science and Health C, Journal of Environmental Chemical Engineering, Water Air \& Soil Pollution, and Marine Biological Association of India ( $1.85 \%$ respectively) category of Web of Science are preferred to explore microplastic and plastic research.

\section{Spatial distribution of microplastics in India}

The concentration, size, and spatial distribution of the microplastic in beach sand (38.64\%), biota (27\%), sediments (11\%), island (7\%), sea salt (4\%), riverine (4\%), lake (4\%), and seawater (2\%) were reviewed from the selected 44 papers.

Page $3 / 30$ 


\section{Microplastics (MPs) in beaches, shores, and coastlines}

The plastic debris concentration average is 204 items $/ \mathrm{kg}$, and about $100 \%$ of total plastic debris is 0.5 to $1 \mathrm{~mm}$ in size found in Silver Beach, Southern India [69]. The polymer types were PVC, PE, and NY identified using ATR-FTIR. The macro-meso-microplastic concentration of 3.77 items $/ \mathrm{m}^{2}, 9.5$ items $/ \mathrm{m}^{2}$, and 54 items $/ \mathrm{m}^{2}$ respectively, and their distribution of macro-meso-microplastics were $54.98 \%, 60 \%$, and $41.17 \%$ and $>2.5 \mathrm{~cm}, 5-2.5 \mathrm{~cm}, 5 \mathrm{~mm}$ in size found in the beaches of Tuticorin Southern India [70]. The polymer types were PE, PP, PET, NY, PS, and PVC identified using ATR-FTIR. [71] reported that the MPs ranged from 60 to 126.6 items $/ \mathrm{L}$ in water and from 50 to 103.8 items $/ \mathrm{kg}$ in sediment, PE fibers (1-3 mm) and PP fragments $(3-5 \mathrm{~mm})$ were the most common forms of microplastics in the Tuticorin and Vembar groups of islands in the Gulf of Mannar, southeast India. [72] reported that the concentration of plastic debris average of 2275 items and about $100 \%$ of total plastic debris is 5.5 to $25 \mathrm{~mm}$ in size found in Marina beach in Chennai, India. The polymer types were LDPE, PE, PP, PA, and PC identified using ATR-FTIR, TGA-DSC, and SEM. The microplastic concentration of $414.35 \mathrm{items} / \mathrm{kg}$, and about $100 \%$ of microplastic ranges from 100-1000 $\mu \mathrm{m}$ in size found in the sediments of the Andaman beaches, India [73]. The polymer types were PP, PMM, PBR, PSF, poly (dimer acid-co-alkyl polyamine), PVC, NY-6, ABS, PBAN, PVF, PPO, and PVB identified using Raman spectral. The plastic debris concentration average of $22.4 \mathrm{~kg}$ dry weight $/ \mathrm{km}^{2}$ and their distribution of $40.6 \%$ in the Northeast Arabian coast, India [74]. The polymer types were identified: plastic bags, styrofoam cups, beverage bottles, bottle caps, plastic rope, net pieces, and food wrappers. The presence of plastic debris concentration of $2 \mathrm{~g} / \mathrm{kg}$ in the seawater of South Juhu creek, Mumbai, India [68]. The microplastic concentration of 385 items $/ \mathrm{kg}$ and their distribution of microplastics were $100 \%$ and 0.5 to $3 \mathrm{~mm}$ in size found in the sediments in coastal areas of Tamil Nadu [77]. The polymer types were PE, PP, NY, PEST, and PS identified using ATR-FTIR and SEM-EDAX.

[78] reported that concentration of microplastic concentration of $220 \mathrm{MPs} / \mathrm{kg}, 181 \mathrm{MPs} / \mathrm{kg}, 45 \mathrm{MPs} / \mathrm{kg}$ (Girgaon Mumbai, Tuticorin beach, and Dhanushkodi beach respectively), and their distribution of microplastics were $100 \%$ and $>1 \mathrm{~mm}$ in size found in the Arabian sea coast, Bay of Bengal coast, India. The polymer types were PET, PE, PVC, PP, PS, PEST, and PA identified using SEM-EDS, Fluorescence microscopy, and FTIR. [79] reported that plastic concentration of $0.55 \mathrm{~kg} / \mathrm{m}^{2}$ and their distribution of $73.8 \%$ in the beaches in Kerala Coast, India. The polymer type was plastic identified. [80] reported that the microplastic concentration of $191 \mathrm{items} / \mathrm{kg}$, and their microplastic distribution is 70\% and 5-1 mm in size found in the Nattika Beach, Kerala Coast, India. The polymer types were PE, PE+PP, PP, PS, and PCU identified using FTIR and SEM. [81] reported that plastic debris concentration of $8.96 \mathrm{~kg} / \mathrm{m}$ and their distribution of $56.42 \%$ in the beach litter along with Chennai, East Coast of India. The food wrappers, cups, bottle and caps, thermocol/styrofoam, and food wrappers were identified. [82] reported that the microplastic concentration of $72.03 \mathrm{MPs} / 100 \mathrm{~g}$ and their distribution of $56.32 \%$ and $300 \mu \mathrm{m}-1 \mathrm{~mm}$ in size found in the beaches of Puducherry, India. The polymer types were PU, HDPE, PP, PS, and LDPE identified using Raman spectroscopy. [84] reported that microplastic concentration of 403 pieces and their distribution of $60.8 \%$ and $>1.01-200 \mathrm{~mm}$ in size found in the Rameswaram beach, GoM, Southeast coast of India. The polymer types were polyethylene, polystyrene, nylon, and polyvinyl chloride identified using FTIR spectroscopy. [85] reported that plastic debris concentration of 505 pieces in the Nallathanni Island, SE of India. The polymer types were PS, PE, PC, PVC, and NY identified using FTIR spectroscopy.

[87] reported that plastic debris concentration was $3.24 \mathrm{~kg}$ and their distribution of $44.89 \%$ in the Marina beach, Chennai, India. [90] reported that plastic debris concentration of $7.49 \mathrm{~g}$ and their distribution of $55.33 \%$ and $1-5 \mathrm{~mm}$ in size found in the beaches in Mumbai, India. The polymer type was plastic identified. [91] reported that the concentration of plastic debris concentration of $3.24 \mathrm{~g} \mathrm{~m}^{-2}$ and their distribution of $80 \%$ and $5-100 \mathrm{~mm}$ in size found in the beaches in Mumbai, India. The polymer type was plastic identified. [60] examined the presence of microplastic concentrations average of $134.29 \mathrm{items} / \mathrm{kg}$ in the sediments and $19.87 \mathrm{items} / \mathrm{L}$ in water, and their distribution of microplastics were $44 \%$ and $58 \%$ in sediments, and water respectively. The particle size range of $1-5 \mathrm{~mm}$, and $500 \mu \mathrm{m}-1 \mathrm{~mm}$ (in sediment and water respectively) along the coast of the Tuticorin, Gulf of Mannar (GoM), India. The polymer types were PE, PP, PP-PE, PA, PET, PEST, PVC, PS, and PVA identified using FTIR-ATR, SEM, and EDAX. [64] examined the presence of microplastic concentrations average of 12.75 items/kg in sediments and 21.60 items/L in seawater, and their microplastic distribution is 100 and $100 \%$, respectively. The particle size ranges from 1-3 $\mathrm{mm}$, and 0.5-1 mm respectively in the Roche Park, Coast of Tuticorin, Gulf of Mannar, Southeastern of India. The polymer types were PE, PP (Magallana bilineata), PE, PP, PEST, PA in sediments, and PE, PP in seawater identified using FTIR-ATR analysis. In quantities of plastic debris is the highest amount of $8.96 \mathrm{~kg} / \mathrm{m}$ in marine beaches to prove that shoreline and recreational activities are the primary cause of beach debris litter along with Chennai, India [81]. 
[95] reported that microplastic concentration of 277.90 items $/ \mathrm{kg}$ and their distribution of $49 \%$ and $0.01-3 \mathrm{~mm}$ in size found in the Island of Maldives, Indian Ocean. The three polymer types were PE, PP, and PS, identified using Celestron Digital Microscope. [96] examined the presence of microplastic concentrations of $0.93 / \mathrm{m}^{3}$ and $45.17 / \mathrm{kg}$ (water, and sediments respectively) in the Port Blair Bay, Andaman Islands. The polymer types were ionomer surlyn, PEI, PAC, PPF, EVOH, PAN, NY, EVA, PI, PU, and PVC identified using FTIR-ATR. [97] reported that plastic debris concentration of 1029 items $/ \mathrm{m}^{2}$ and their distribution of $96 \%$ and $>1 \mathrm{~mm}$ in size found in the Island of the Maldives, Indian Ocean. The polymer types were PE, PP, PS, PU, PA, PVA, and PVC identified using ATR-FTIR spectroscopy.

[98] examined the presence of microplastic concentrations of 288 pieces $/ \mathrm{m}^{3}, 96$ pieces $/ \mathrm{kg}, 84.45 \mathrm{pieces} / \mathrm{kg}$ in water, sediments, and soil, respectively), and their distribution of microplastic is $86.51 \%$. The particle size range of $1-5 \mathrm{~mm}$ and $0.3-1 \mathrm{~mm}$ in the Netravathi river, India. The polymer types PE, PET, PP, and PVC were identified using FTIR-ATR. Due to its widespread usage as packaging materials, higher polyethylene abundance is the primarily used plastic raw material in Indian industries [140]. Compared with other rivers, In Portugal's Antua River, microplastics abundance ranged from 13.5 to $52.7 \mathrm{mg} / \mathrm{kg}$ in March, and 2.6 to $71.4 \mathrm{mg} / \mathrm{kg}$ in October [141], higher than Haihe River [142] and marginally lower than Pearl River [143, 144]. [99] examined that MPs concentration ranges from 0.68 to $148.31 \mathrm{ng} / \mathrm{g}$ and 11-64 $\mathrm{ng} / \mathrm{g}$ items $/ \mathrm{kg}$ and their distribution of $70 \%$ and 5 to $10 \mathrm{~mm}$ in size found in the sediments of Ganga riverine, India. The polymer types were PET, PE, PP, and PS identified using FTIR. This degree of microplastic abundance was found to be smaller than other world rivers. Likewise, plastic debris concentration ranged from 228 to 3760 items $/ \mathrm{kg}$ in the Rhine river [145], 178-544 items/kg in the Beijiang river [119], and $185-660$ items $/ \mathrm{kg}$ in the Thames river [32], which is less than previous.

The numerical fraction of microplastics in the Ganga was identified higher compared to the concentration of microplastic ranges from $0.60-$ 160 items $/ \mathrm{kg}$ in the Bloukrans river, South Africa [146]. This disparity in the concentration of meso and microplastics in these rivers is due to several factors, including pollutant loading, hydrodynamic state, and spatial location [147, 148]. Depending on these considerations, certain places were observed to have large concentrations of plastics relative to others. PET, PE, and PP were the most popular plastic forms in Ganga river sediments, while fibers (polyesters) and sheet or film were the most significant morphotypes. Microplastic waste highlighting fibers was recently emphasized compared to other morphotypes such as film and beads [149].

[75] reported that microplastic concentration of 343 items $50 \mathrm{~g}^{-1}$ d.s. and their distribution of $100 \%$ and $<5 \mathrm{~mm}$ in size found in the southernmost coast of India (Kanyakumari), India. The polymer types were fiber and fragment identified. [76] examined the presence of microplastic concentrations of 40.7 particles $/ \mathrm{m}^{2}, 1.25$ particles $/ \mathrm{m}^{3}, 22$ particles in sediments, water, and fish, respectively), and their microplastic distribution is $96.10 \%$. The particle size range of $0.3-0.6,0.6-1.18$, and $1.18-2.36 \mathrm{~mm}$ in Kerala, Southwest India. The polymer types PE, PP, PA, PS, PET, RY, CE, ABS, PVC, sediments, PE, PP, RY, PS, and CL in water, and PE, CE, RY, and PP in fish identified using FTIRATR, and FP-XRF. [86] reported that microplastic concentrations of 496 items $\mathrm{m}^{-2}$ and their distribution of $91 \%$ and $<5 \mathrm{~mm}$ in size were found in the Vembanad Lake, Kerala, India. The polymer types were PP, PE, and PS identified using Raman spectra. [88] reported that a microplastic concentration of 3000 pellets was found on the Goa coast, India. The polymer types were PE and PP identified using FTIR-ATR. [150] reported that microplastic concentration of 1200 pellets 2 to $5 \mathrm{~mm}$ in size found in the Chennai coast, India. The polymer types were PE and PP identified using FTIR-ATR.

[92] examined the presence of microplastic in sea salt, and their distribution of microplastic is $60 \%$. Particle size of $100 \mu \mathrm{m}$ was found in the Tuticorin coastal salt pan stations, Gulf of Mannar, South India. The polymer types PE, PP, CL, and NY were identified using $\mu F T I R$ and AFM. In heavily polluted surface waters, MPs were also recently reported from Arctic sea ice, fish, sea birds, and sea salts. Only a small range of global studies have been carried out on the quantity and distribution of MPs in marine salts [151-155]. [93] reported that microplastic concentration of 72 items $/ \mathrm{kg}$ and their distribution of $100 \%$ and 100 to $500 \mu \mathrm{m}$ in size found in the sea salt in the Salt of Tuticorin, Southeast Coast of India. The polymer types were PE, PP, PEST, and PA identified using SEM-EDAX. The study shows that people consume around $216 \mathrm{MPs} /$ year particles through sea salt if the average individual consumes 5 grams of salt per day.

[94] investigated the MPs concentration of 103 particles $\mathrm{kg}^{-1}$ and their distribution of $80 \%$ and $2000 \mu \mathrm{m}$ and $500 \mu \mathrm{m}$ in size found in the sea salt in the Mumbai, Indian sea salts, Southeast Coast of India. The polymer types were PEST, PS, PA, and PE

Page 5/30 
identified using $\mu F T I R$. Microplastic abundance in sea salts may be due to sea salt being a direct product of coastal water. The number of MPs in the salt samples tested by this analysis was smaller than in China and Spain's sea salts and well salt [156, 157]. Low-density MPs may also be transferred from surface soil to deeper soil levels horizontally and vertically through soil fractures as well as by earthworms, collembolan, and other species [158-161]. It may also be affected by airborne pollution [157, 162, 163].

[100] examined the presence of microplastic concentrations of 309 items $/ \mathrm{kg}, 28$ items $/ \mathrm{km}^{2}, 5.9$ items $/ \mathrm{L}$ in sediments, and water respectively), and their microplastic distribution is $80 \%$. The particle size range of -1 to $0.3 \mathrm{~mm}, 0.3-2 \mathrm{~mm}$ in the Veeranam lake, Tamil Nadu, India. The polymer types such as NY, PE, PS, PP, and PVC were identified using ATR-FTIR. [101] examined the presence of microplastic concentrations of 5.9 particles $/ \mathrm{L}, 27$ items $/ \mathrm{kg}$, in water and sediments respectively), and their distribution of microplastic is $99 \%$. The particle size range of $0.33-2 \mathrm{~mm}$ in water, $2 \mathrm{~mm}$ in sediments of the Red Hills Lake, India. The polymer types were HDPE, LDPE, PP, and PS identified using ATR-FTIR, SEM. The causative factors of these microplastics are primarily attributed to the weathering phase degradation of plastic goods and even from fishing nets, as these are the significant contributors of microplastics in water and sediments [164-166]. A further probable route for microplastic is by dry deposition, by wind transport. The dust generated by, i.e., automotive emissions, tires [167] from the soil, deposition, and dispersion between the atmosphere, the environment, and the marine domain may also promote the transportation of microplastic [168]; however, this requires detailed analysis [169].

\section{Ecotoxicological effects of microplastics on biota}

Microplastic particles were found in many aquatic biota, such as fishes (Anodontostoma chacunda, Arius arius (11), Carangoides armatus (20), Chirocentrus dorab (20), Coilia dussumieri (10), Cyanoglossus macrostomus (126), Decapterus russelli (10), Dussumieria acuta, Dussumieria elopsoides (10), Eleutheronoma tetradactylum (10), Epinephalus diacanthus (8), Epinephalus merra, Escualosa thoracata (10), Harpodon nehereus (20), Istiophorus platypterus (10), Katsuwonus pelamis (10), Leiognathus equulus (10), Leiognathus splendens (6), Megalaspis cordyla, Mugil cephalus, Nemipterus japonicas (20), Nemipterus randalli (38), Pentaprion longimanus (20), Piaractus brachypomus, Rastrelliger faughni (10), Rastrelliger kanagurta (168), Sardinella albella (20), Sardinella gibbosa (41), Sardinella longiceps (144), Saurida tumbil (13), Scomberomorous guttatus (10), Siganus javus (29), Sphyraena obtusata, Stolephorus indicus (148), Terapon puta (33), Thryssa dussumieri, and Thryssa mystax (12); Shrimp (Fenneropenaeus indice - 330), bivalve (Perna viridis \& Meretrix meretrix -50), mollusca (Donax cuneatus (225), Perna viridis (Linnaeus, 1758), oyster (Magallana bilineata), Annelida (Sternaspis scutata, Magelona cinta and Tellina sp), and zooplankton - copepods (100), chaetognaths (50), jellyfish (50), and shrimps (20), fish (72). Fourteen studies reported the intake of microplastics by aquatic species in India. From these researches, 1895 aquatic organisms were analyzed, and more than $95 \%$ of the species studied were infected by microplastic particles (Table 1).

\section{Microplastics (MPs) invertebrates}

Two primary mechanisms absorb microplastics into vertebrates: predators feed on food already infected with microplastics (through intake or external microplastic), or predators directly absorb microplastics from the water and sediments. Microplastics in different forms were found in 1470 no. of fishes (52 species) in India (Table 1).

Microplastics were present in the gut and intestine of fishes, namely as Dardanelle longiceps (123), Rastrelliger kanagurta (130), Dardanelle gibbosa (40), Carangoides armatus (20), Stolephorus indicus (127), Epinephalus diacanthus (8), Saurida tumbil (13), Terapon puta (13), Nemipterus randalli (38), Leiognathus splendens (6), Cyanoglossus macrostomus (106), and Thryssa mystax (12). The particle size range from $>1-5 \mathrm{~mm}$ and $81.59 \%$ distributed in fishes of Kochi, southeastern Arabian Sea, India [56]. The polymer types were PE, PP, LDPE identified using Raman spectroscopy and FTIR. Average microplastic concentrations of 0.2002 items/g were found in gastrointestinal tracts of fishes and 13.4 items/L in seawater, and their distribution of microplastic is 34\% and 64\% (fish and seawater, respectively) [60]. The particle size range of $<500 \mu \mathrm{m}$, and $1-5 \mathrm{~mm}$ (in guts and seawater respectively) in Tuticorin, Southeast coast of India. The polymer types were PE, PA, PEST, PS, PP, and PAC in fishes, and PE, PEST, PA, PS, PP, PD, PP-PE, and PLA in seawater identified using FTIR-ATR and SEM-EDAX. [57] examined the presence of microplastic concentrations average of 0.005 items $/ \mathrm{g}$ in edible tissues and 0.054 items/g in inedible tissues of fishes, and their distribution of microplastic is $11.6 \%$ and $88.4 \%$ (edible and inedible tissues, respectively). The particle size ranges from 115-210 $\mu \mathrm{m}$ and 136 to $4010 \mu \mathrm{m}$ (edible and inedible tissues respectively) in Kerala, India. The polymer types were PE, PP in edible tissues and PE, PP, EPDM, PS in inedible tissues of fishes identified using ATR- FTIR.

Page 6/30 
[61] reported the microplastic concentration is 26.01 items/g in the gut of the alien fish of Piaractus brachypomus (123). The particle size of $0.5 \mathrm{~mm}$ and their distribution of $99 \%$ in the Ramsar, Vembanad lake, South India. The polymer types were PBT, PP, PET, and NY 6 identified using ATR-FTIR and Raman spectroscopy. The microplastic concentration of 20 items/g in the gastrointestinal tract of fishes such as Coilia dussumieri (10), Decapterus russelli (10), Decapterus macarellus (20), Dussumieria elopsoides (10), Eleutheronoma tetradactylum (10), Escualosa thoracata (10), Nemipterus japonicas (20), Pentaprion longimanus (20), Rastrelliger faughni (10), Sardinella longiceps (20), Scomberomorous guttatus (10), Stolephorus indicus (20), and Terapon puta (20) [62]. The particle size ranges from 1.3 $\mu m$ $9.3 \mathrm{~mm}$, and their distribution of $8.95 \%$ in the Chennai and Nagapattinam, the Southeast coast of the Bay of Bengal. The polymer types were PA, PE, and PET identified using FTIR \& SEM.

About $80 \%$ distribution of the microplastic is found in the intestine of Rastrilleger kanagurta (20) and Epinephalus merra (20) [65]. The particle size ranges from $0.5 \mathrm{~mm}$ to $1 \mathrm{~mm}$ in the Tuticorin, Southeast coast of India. The polymer types were polyethylene \& polypropylene identified using FTIR. [83] examined the microplastic concentrations of $46.6 / \mathrm{m}^{2}$ in the gut of Rastrelliger kanagurta (17), Siganus javus (29), Arius arius (11), Leiognathus equulus (10), and Mugil cephalus (12) (Fishes), 9233mg/m² in sediments, and their distribution of microplastic are $60.1 \%$ respectively. The particle size ranges from $1-2.5 \mathrm{~mm}$ respectively in the beaches of the Southeast coast of India. The polymer types were PE, PP, PS, and NY identified using FTIR-ATR analysis. Microplastic concentrations of 10.65 specimens in finfish \& shellfish, and their distribution of microplastics were $45.83 \%$ in fishes such as Alepes djedaba (6), Cynoglossus lida (6), Saurida tumbil (9), Gerres filamentous (13), Nemipterus peronii (8), Upeneus vittatus (10), Carangoides malabaricus (4) (Adult), and Carangoides malabaricus (6) (Juveniles), and shellfish. The particle size range of 111.58 to $5094 \mu \mathrm{m}$ in finfish \& shellfish in the Port Blair Bay, Andaman Islands, India [96]. The polymer types were PEI, PAC, PPS, EVOH, PAN, NY, PEVA, PI, PU, PVC identified using FTIR-ATR.

In conditions of particles per organism, larger vertebrates have eaten higher concentrations of microplastics than fish. The highest microplastic abundance values were reported on southeast coast of India [96]. By examining microplastic abundance in fish from different studies in India, it is clear that microplastics abundance in Indian fish was of the same magnitude as in other countries. For particles per weight, microplastic was identified in Istiophorus platypterus showed in the Tuticorin, Southeast coast of India, which had an abundance of $0.0002 \mathrm{MP} / \mathrm{g}$ in the gut $1.10 \mathrm{MP} / \mathrm{g}$ in body, and $0.11 \mathrm{MP} /$ individual due to depth about $>200 \mathrm{~m}$ [93]. The depth of locations, the microplastic concentration of $0.2 \mathrm{MP} / \mathrm{g}$ in the gut, $0.008 \mathrm{MP} / \mathrm{g}$ in body, and $3.64 \mathrm{MP} /$ individual was found to be Harpodon nehereus due to depth above 1-3 m. In particles per weight, microplastic was found to be Piaractus brachypomus showed in the Ramsar, Vembanad Lake, south India, which had $26 \%$ MP intake in fish [61].

\section{Microplastics (MPs) in invertebrates}

Microplastic toxicity has been observed in the ecological food web, influencing both the basal food web species and all kinds of species [114]. Indian invertebrate absorption of microplastic particles was studied in bivalves, shrimps, and other benthic species. At present, six studies analyzed the microplastic contamination in invertebrates in India, and 508 organisms are reported to be microplastic polluted (Table 1). Bivalves are of particular concern among these species since their extensive filter-feeding practices expose them to plastics in the waters $[110,170]$. The confirmed rate of microplastic ingested by aquatic invertebrates was $58.58 \%$. The microplastic abundance in marine invertebrates in India ranged from 0.04 to 3.78 and from 0.39 to 7.05 items $/ \mathrm{g}$. [57] Microplastic is 0.04 items $/ \mathrm{g}$ (0.39 \pm 0.6 items/shrimp) in the foregut and midgut of Fenneropenaeus indices (Shrimp - 330). The particle size range from 500 to $1000 \mu \mathrm{m}$, and $30.9 \%$ are distributed in Cochin, Kerala, India. The polymer types were PA, PEST, PE, and PP identified using FTIR.

[58] reported the presence of microplastic is $3.78 \mathrm{~g}$ and 7.05 items $/ \mathrm{g}$ (soft tissue and bivalve respectively) in the Perna viridis (90) and Meretrix meretrix (110). The particle size range of < $100 \mu \mathrm{m}$ in the Pondicherry, India. The polymer types were PA, PEST, PE, and PP identified using Raman spectrum \& Fluorescence microscope. [59] examined the presence of microplastic concentrations average of 0.95 items/g in clams (Donax cuneatus - 225), and their distribution was $41 \%$ Donax cuneatus. The particle size range of $100-250 \mu m$ in clams in the Tuticorin coast of Gulf of Mannar (GoM), India. The polymer types were PE, PP, PP-PE, PA, PET, PEST, PVC, PS, RA, and PVA identified using FTIR-ATR, SEM, and EDAX. [63] examined that presence of microplastic concentration is $0.9 / \mathrm{g}$ in the tissue of Perna viridis (Linnaeus, 1758) (5). The particle size ranges from 5-30 $\mu \mathrm{m}$, and their distribution of $87 \%$ in Chennai, the Southeast coast of India. The polymer type was PS

Page $7 / 30$ 
identified using DXR Raman spectroscopic. [64] examined the presence of microplastic concentrations average of 0.81/g in Magallana bilineata (oyster) (180), and their distribution of microplastic is $96 \%$. The particle size ranges from 0.25 to $0.5 \mathrm{~mm}$ in the Roche Park, Tuticorin coast, GoM, SE India. The polymer types were PE; PP (Magallana bilineata) identified using FTIR-ATR analysis. [66] examined the distribution of microplastic $67 \%$ in the gut of Sternaspis scutata, Tellina sp, and Magelona cinta. The particle size range of $20 \mu \mathrm{m}$ in the Kochi, Southeastern Arabian Sea. The polymer types were polystyrene identified using a DXR Raman microscope.

[96] analyzed the microplastic concentration in 10.65 specimens, 0.12 pieces (finfish \& shellfish, and zooplankton), and their distribution is 45.83 percent, $90 \%$ in finfish \& shellfish, zooplankton, respectively. Port Blair Bay, Andaman Islands, the particle size spectrum is 111.58 to $5094 \mu \mathrm{m}, 21.57$ to $2225 \mu \mathrm{m}$ (finfish \& shellfish and zooplankton, respectively). Polymer forms were PEI, PAC, PPS, EVOH, PAN, NY, PEVA, PI, PU, and PVC were identified using FTIR-ATR. In terms of particles per individual, the highest concentration of microplastics was noticed in Magallana bilineata (oyster) collected in the Roche Park, Tuticorin coast, GoM, Southeastern India, which has an abundance of 29.19 items/ individual and 1.73 MPs items/g [64]. Similarly, the largest concentration of microplastics was found in oysters (Crassostrea gigas) obtained in Sangou Bay, Yellow Sea, with a concentration of 43-164 ind. ${ }^{-1}$. By contrasting the abundance of microplastic in commercial invertebrates in China and other countries across the world, Chinese microplastic emission levels were found to be generally higher than in other countries.

\section{Microplastics (MPs) size in different aquatic environments and biota}

A primary element affecting the ingestion of microplastic particles is their small size, as many low-trophic species have little potential to turn plastic from food and feed upon it, which is reasonable in size [118, 171]. In general, size was also strongly linked to microplastics toxicity [172]. In the 53 reviewed papers, 35 researchers recorded the size spectrum (Table 1). The highest value varied from $9.3 \mathrm{~mm}$ to $5 \mathrm{~mm}$, and the minimum values ranged from 0.005 to $1 \mathrm{~mm}$. Most investigations have found microplastics in the size class of less than $1 \mathrm{~mm}$ ( 83 percent of biota articles). However, larger microplastics overshadowed particular fish research. For example, larger microplastics were identified in fish (0.0013-9.3 mm) from Chennai and Nagapattinam, Southeast Bay of Bengal [62], fish captured from the Kochi, southeastern Arabian Sea, India (particle size range from > 1-5mm [56], fish (inedible tissues) captured from Kerala, India (Size: 0.136 to $4.010 \mathrm{~mm}$ [57], fish (gut) caught from the beaches of the southeast coast of India (Size: 1-2.5mm [83], Shrimp captured from the Cochin, Kerala, India (Size: 0.5-1 $\mathrm{mm}$ ), the plastic debris size ranges from $0.5-25 \mathrm{~mm}$ in the beach sediments. In marine Chennai, the beach has been size in $5.5-25 \mathrm{~mm}$ in beach sediments [72]. The irregular plastic particles are produced mainly from dampening household plastic materials by urban drainage and partly by sea. Previous reports indicate a higher distribution of fragments and fibers than other sources in coastal sediments [173-175]. Polymer types such as PE, PP, and PS float on seawater and fly long stretches, located far from their primary origins [176].

\section{Comparison of global research in microplastics}

\section{Microplastics in the China coastal regions}

According to [177], the prevalence of microplastics in Jiaozhou Bay, Shandong Peninsula, northern China, ranges from 2.5 items/kg d.w. to 27.5 items/kg d.w., with nearly $80 \%$ of total microplastic ranging from 0.1 to $5 \mathrm{~mm}$ in size. The total microplastics in the sediment in Jiaozhou Bay were estimated to be 3.71 tonnes. The $\mu$-FTIR spectroscopy analysis has been used to identify polymer types such as PMMA, PE, PA, PET, PU, RY, PP, and PE-PS. [178] explained that the East China Sea has an abundance of plastics ranging from 375.44 items/km² and nearly $95 \%$ of total plastic ranging in size from $1.3 \mathrm{~cm}$ to $14.23 \mathrm{~cm}$. The $\mu$-FTIR spectroscopy was used to identify several polymer types such as PC, PVC, PP, PET, PE, and PS. [179] observed that the abundance of microplastics in the Sanggou Bay, China, varies from $1674 \pm 526$ items $/ \mathrm{kg}$ and comprises $57.72 \%$ microplastics with a size range of $0.5 \mathrm{~mm}$. Particles were counted and photographed. PE, PP, PS, CL, and PC were identified by an optical microscope using $\mu$-FTIR spectroscopy. [180] assessed the abundance of microplastics in the Nansha Islands, South China Sea, which ranged from $0.0556 \pm 0.0355$ items $/ \mathrm{m}^{3}$ and accounted for almost $70 \%$ of total microplastics in the $3 \mathrm{~mm}$ range. [181] observed the abundance of microplastics in the Laizhou Bay, China, ranging from $461.6 \pm 167.0$ to 193 to 1053 particles/kg, with about $94.10 \%$ microplastics in the $3 \mathrm{~mm}$ size range. $\mu$-FTIR spectroscopy was used to identify the microplastics, mostly PEA, CP, PET, PP, PVA, PPA, and PVC. According to [182], the concentration of microplastics in the Chinese coastline is $309 \pm 81$ items/kg, with 71.5 percent of total microplastics with a size range of $2411 \mu \mathrm{m}$. $\mu$-FTIR spectroscopy was used to identify several polymer types such as PP, PET, and RY. [183] studied the abundance of microplastics in the Hangzhou Bay, China, is $84.3 \pm 56.6$ items $/ \mathrm{kg}$, with almost $38 \%$ of total microplastic in the $<1.0 \mathrm{~mm}$ size range. They used $\mu$-FTIR to identify polymer types, including PE, PP, PET, cellulose, and PP-PE. According to [184], the

Page $8 / 30$ 
concentration of microplastics in Haikou Bay, Northern South China Sea, ranging from $0.66 \pm 0.58 \mathrm{n} / 50 \mathrm{~g}$ (d.w.), $17.00 \pm 6.56 \mathrm{n} / 50 \mathrm{~g}$ (d.w.) and about $83.12 \%$ of total microplastic is 1 to $1.9 \mathrm{~mm}$ in size. FTIR was used to identify seven polymer types, including PP, PVC, PMMA, PS, PE, PP-PE, and PU.

According to [185], the Bohai Sea Coastline has a microplastic concentration of $458.6 \pm 150.0$ items $/ \mathrm{kg}$, with $77.1 \%$ of total microplastic being $<1500 \mu \mathrm{m}$ in size. Using $\mu$-FTIR, they were able to identify seven polymer types, including ABS, PE, PP, PA, PET, PS, and RY. In southern China, [186] identified an abundance of microplastics ranging from 2249 items $/ \mathrm{kg}$ to $75 \%$ of total microplastics ranging from $3 \mathrm{~mm}$ in size. SEM and energy-dispersive X-ray spectroscopy studies were used to identify the microplastics, mostly made of PP, PE, and PS. According to [187], the abundance of microplastics in Sishili Bay, North Yellow Sea, China, ranges from $499.76 \pm 370.07$ items $/ \mathrm{kg}$, with about $86.37 \%$ of total microplastic ranging from $746.84 \pm 839.69 \mathrm{~m}$ in size. FTIR spectroscopy analysis was used to identify polymer types such as PMMA, PE, PA, PET, PU, RY, PP, and PE- PS. [188] reported that the concentration of microplastics in the Zhubi reef in the South China Sea ranges from 1400 to 8100 items $/ \mathrm{m}^{3}$, with $80 \%$ of total microplastic in the $0.5 \mathrm{~mm}$ size range. They used SEM and a DXR2 micro-Raman spectrometer to identify two polymer types: PP and PA. [189] explained that the microplastic concentrations in the Yellow Sea and the East China Sea are $13.4 \pm 0.6$ particles per $100 \mathrm{~g}^{-1}$, with $89 \%$ microplastic in size range of $1000 \mu \mathrm{m}$. Using $\mu$-FTIR, they identified two polymer types: PP and PA. [190] investigated the abundance of microplastics in the Rudong Offshore Wind Farm, Yellow Sea, China, finding $2.58 \pm 1.14$ items $/ g$ and $68.7 \%$ of total microplastics ranging from 0.1 to $5 \mathrm{~mm}$ in size. PPA, PVC, and PE were detected as microplastics in the samples. For the chemical identification of polymers, a micro-Fourier transform infrared spectroscope ( $\mu$-FTIR) was used. [191] observed that the abundance of microplastics ranges from $15-12,852$ items $/ \mathrm{kg}$ and that $61.3 \%$ of microplastics vary from 0.16 to $5.0 \mathrm{~mm}$ in size in Qinzhou Bay, China. FTIR spectroscopy was used to identify the three types of microplastics: PP, PE, and PS. In the Maowei Sea, South China, [192] reported that the microplastic concentrations vary from $520 \pm 32$ to $940 \pm 17$ items $/ \mathrm{kg}$, with around $75 \%$ microplastic in size range $<1 \mathrm{~mm}$.

[193] found that the concentration of microplastics on Guangdong, South China, coast ranged from $16,686 \mathrm{items} / \mathrm{m}^{2}$. Microplastics ranged from 0.315 to $5 \mathrm{~mm}$ and were distributed at $83 \%$ in the study location. Spectroscopy analysis was used to identify the microplastics, mostly made of PP and PE (FTIR and Raman). In the Changjiang Estuary, China, [194] found a concentration of microplastics of $121 \pm 9$ items per $\mathrm{kg}$. Microplastics range in size from 1 to $5 \mathrm{~mm}$. The $\mu$-FTIR spectroscopy study revealed that the microplastics were RY, PEST, PAC, PE, PP, PD, and PS. [195] found that the concentration of microplastics in the estuaries of Jiaojiang, Oujiang, and Minjiang in China ranged from $100 \mathrm{n} / \mathrm{m}^{3}$ to $4100 \mathrm{n} / \mathrm{m}^{3}$ is $90 \%$. Micro-Raman spectroscopy is used to identify the microplastics, mostly made of PP, PE, PVC, and PTFE. [196] reported the abundance of microplastics with a size range of 8714 (Items $/ \mathrm{kg}$ in sediment). About $82 \%$ of microplastics with a size range of $5 \mathrm{~mm}$ have been detected in the Beibu Gulf and China Sea coastline. PP, PET, PEST, and PS were identified as four forms of microplastics. Fluorescence microscopes were used to count the number of microplastics. According to [197], the number of microplastics in debris on the northern South China Sea beaches ranged from 375 items $/ \mathrm{km}^{2}$ to $42 \%$ of total microplastic size $5 \mathrm{~mm}$.

\section{Atlantic Ocean}

[198] found 15,283 items $/ \mathrm{km}^{2}$ of plastic in the Macaronesian region of the NE Atlantic. The size of microplastics in this area ranges from 1-5 $\mathrm{mm}$. [197], studied the abundance of microplastics in Tenerife beaches was $3.5 \mathrm{~g} / \mathrm{m}^{2}$, with $78 \%$ of total microplastic ranging in size from 1 to $2 \mathrm{~mm}$ (Canary Islands, Spain). FTIR spectrometry is used to determine the composition of microplastics such as polypropylene and polyethylene. [200], explained the abundance of microplastics ranges from $8.5 \mathrm{~g} / \mathrm{m}^{2}$ to $103.4 \mathrm{~g} / \mathrm{m}^{2}$, with $87 \%$ microplastic size $5 \mathrm{~mm}$ was reported in Lanzarote's biosphere reserve in the combination of PE, PP, and PS. The chemical identification of polymers was made using Raman and FTIR spectroscopy. [201] The quantity of microplastics in the Mar Menor lagoon ranges from $186.1 \pm 8.1 \mathrm{~g}$ and $84.2 \%$ of the total microplastic size of $5.0 \mathrm{~mm}$ (SE Spain). FTIR spectroscopy is used to determine the composition of microplastics such as PEST, PVE, PP, PS, PE, PVCAP, and PE. [202] reported the microplastic content of 0-12,869 items/ $\mathrm{m}^{2}$ on the beaches of the Canary Islands. Microplastics range from 1-5 mm and are distributed in $52.7 \%$ of the total microplastic. [203] found a plastic abundance of 67 ( \pm 76 ) $\mathrm{MPs} / \mathrm{kg}$ in the French Atlantic coastline. Microplastics range in size from 50-100 $\mu \mathrm{m}$, with $84 \%$ of the distribution. PP and PE constitute the majority of the microplastic composition. [204] found $7.49 \mathrm{~g}$ and $68.83 \mathrm{items} / \mathrm{m}^{2}$ of microplastic in the Atlantic Ocean at Bremerhaven, Germany, and Cape Town, South Africa, with abundance values ranging from $1.15 \pm 1.45$ particles $\mathrm{m}^{-3}$. The research area has a distribution of $94 \%$ of microplastic. [205], the Atlantic Ocean contains 13 to 501 items $\mathrm{m}^{-3}$ of microplastics. The microplastic size ranged from 50-80 $\mu \mathrm{m}$, with a $42 \%$ microplastic distribution in the research region. Microplastic is made up of PE, and PP, which can be analyzed using FTIR. In 
the Atlantic Ocean, [206] found 0.5 microplastics per $25 \mathrm{~cm}^{2}$ (Porcupine Abyssal Plain, Lobe of Congo Canyon Atlantic and the Mediterranean Sea). Microplastics are found in sizes ranging from $75 \mathrm{~mm}$ to $161 \mathrm{~mm}$. According to [207], the abundance of microplastics in Saint Peter and Saint Paul Archipelago, equatorial Atlantic, ranges from 0.34 to $20.81 \mathrm{~g} \mathrm{~m}^{-3}$, with microplastics ranging in size from $25 \mathrm{~mm}$. [208], analyzed that the microplastics are abundant in the South Pacific subtropical gyre, with 26,898 particles per $\mathrm{km}^{2}$ and $88.8 \%$ of total microplastic ranging in size from 0.355 to $4.75 \mathrm{~mm}$ with the composition of PS fragments, pellets, PP/monofilament line, and film.

\section{United States of America region}

[209] explained that the concentration of microplastic in Virginia and North Carolina is $1410 \pm 810$ per kg. Microplastics in the research area range in size from 5.0 to $0.5 \mathrm{~mm}$, with a distribution of $93.91 \%$. Using Raman microspectroscopy, the composition of microplastics was found to be fiber and PE, PS, NY, PP, PVBP, and PET. The Charleston Harbor Estuary, South Carolina, USA, [210] reported microplastic concentration to be 652 microplastics/ $\mathrm{m}^{2}$. The microplastic size is $\geq 500 \mu \mathrm{m}$, and the distribution in the studied area is $26.2 \%$. ATR-FTIR is used to determine the fiber composition of microplastic. In the sediments of Todos Santos Bay, Mexico, [211] found microplastic concentrations of 0.01 to 0.70 plastic particles $/ \mathrm{m}^{3}\left(\mathrm{pp} / \mathrm{m}^{3}\right)$. In the study area, particles with sizes ranging from 500 to $250 \mu \mathrm{m}$ were identified. In Tampa Bay, Florida, [212] found 280 ( \pm 290$)$ particles/kg microplastic concentration. The region has a microplastic size range of $5 \mathrm{~mm}$ and a distribution of $42 \%$ of microplastic with the combination of fiber and PE and can be detected using a microscope (33x). On the

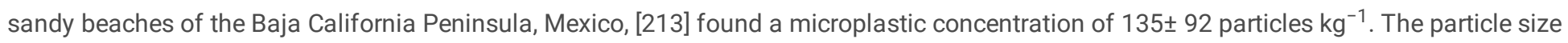
of $1 \mathrm{~mm}$ has been determined, and the microplastic distribution in this region is $91 \%$. The microplastics are separated using the density method, and the microplastics are identified using the ATR-FTIR. [214] found microplastic concentrations of $413.8 \pm 76.7$ and $221.0 \pm 25.6$ particles $/ \mathrm{m}^{2}$ in beach sediments in the South Carolina estuaries (Charleston Harbor, Winyah Bay, and South Carolina, respectively). The particle sizes range from 63-149 $\mu \mathrm{m}$, and their distribution in this area is $73 \%$. SEM was used to identify the four polymer types: NY, PEST, $\mathrm{PE}$, and PP in the San Francisco Bay, California, USA, [215] observed a particle concentration of 700,000 particles/ km². In this region, microplastic with a diameter of $0.125-0.355 \mathrm{~mm}$ with the combination of PE and PP are identified using infrared or Raman spectroscopy. Microplastic concentrations of $69 \mathrm{~g}$ were found on tourist beaches in Huatulco Bay, on the Pacific coast of southern Mexico, as reported by [216]. [217] studied that the particle size is $5 \mathrm{~mm}$ with the microplastic concentrations of $4.0 \pm 1.03 \mathrm{mg}$ were found in barrier islands across the northern Gulf of Mexico. The particle size ranges from $2.5 \pm 0.48 \mathrm{~mm}$, with a microplastic distribution of $47.8 \%$ in this area. [218], analyzed the concentration of microplastic in the Canadian Lake Ontario nearshore is 500 particles per kg. In the study area, the microplastic size range is $2 \mathrm{~mm}$. PMMA, PDMS, PU, ABS, PSS, PVAC, NY, and RPP. Raman spectroscopy and X-ray fluorescence spectroscopy were used to identify microplastics. [219] explained the Chesapeake Bay has a microplastic content of $560 \mathrm{~g} / \mathrm{km}$. Microplastics in the research area range in size from 0.3 to $5.0 \mathrm{~mm}$, with a distribution of $93.91 \%$ with the composition of synthetic fibers and polystyrene were identified using Raman microspectroscopy.

\section{Mediterranean Sea}

[220] reported the abundance of microplastic ranges from $182.66 \pm 27.32$ and $649.33 \pm 184.02 \mathrm{~kg}^{-1}$ and about $70 \%$ of total microplastic ranges between 0.81 to $2.16 \mathrm{~mm}$ in size surface sediment microplastics and litter from North African coasts of Mediterranean sea. [221] studied the abundance of microplastics range of $280.3 \pm 164.9 \mathrm{MPs} / \mathrm{kg} \mathrm{d}$.w. About $85 \%$ of the total microplastic size of $1.2 \mu \mathrm{m}$ was found in the Spanish Mediterranean. The composition of microplastic such as fibers, fragments, and fibers was identified. [222] reported the concentration of microplastic ranges from $2073.3 \pm 648.6$ particles $\mathrm{kg}^{-1} \mathrm{~d}$.w. About $72 \%$ of total microplastic ranges from 1 to $5 \mathrm{~mm}$ in size are found in the Aegean and Mediterranean Seas, Datca Peninsula (Turkey). [223] reported that the concentration of microplastic ranges from 33 to 798 microplastics per $\mathrm{kg}$. About $63 \%$ of total microplastic is $0.5 \mathrm{~mm}$ in size found in the northwestern Mediterranean sea. [224] studied the abundance of microplastics range of $734 \mathrm{~g}$, and about $93 \%$ of the total microplastic size of $2 \mathrm{~mm}$ was found in the coastline of Northern Crete. The composition of microplastic such as PEST, PAHs is identified using GC-ITMS. [225] reported the abundance of microplastics ranges from $141.20 \pm 25.98$ to $461.25 \pm 29.74$ items kg-1 and about $85.71 \%$ of total microplastic ranges between 0.1 to 5 $\mathrm{mm}$ in size found in the north Tunisian coast (Mediterranean Sea). [226] examined the abundance of microplastics ranges from $0.90 \pm 0.10$ $\mathrm{MPs} / \mathrm{g}$, and about $60 \%$ of total microplastic is in the range of $2 \mathrm{~mm}$ in size is found in the Mediterranean Sea. [227] reported that plastic concentration of 24 to 1211 items $/ \mathrm{km}^{2}$ in the eastern Mediterranean and Black seas. Plastics were predominant in all study areas ranging from $45.2 \%$ to $95 \%$. [228] reported a plastic concentration of $1462 \mathrm{~m}^{2}$ on the island of Malta (Central Mediterranean). The distribution of plastic is $78.5 \%$ in the study area. 


\section{Baltic coast}

[229] reported that concentration varied between 76 and 295 items per kg dry sediments in the southern Baltic Sea. Microplastic size is 500 $\mu \mathrm{m}$, and the distribution of microplastic is $91 \%$ in this area. [230] studied that abundance of 88.10 microplastic particles per kg dry sediment was found at the Isle of Rugen, Baltic Sea. Microplastic size ranges from $>1$ to $5 \mathrm{~mm}$ and $>0.63$ to $1 \mathrm{~mm}$ in this region and $80 \%$ distribution. [231] reported that microplastic concentration of 7-5560 (42-1150) items per $\mathrm{m}^{2}$ in the Baltic beaches of Kaliningrad region, Russia. Microplastic size ranges from 0.5-5 mm in this region. [232] studied that microplastic concentration of 0-27 particles kg ${ }^{-1}$ in beach sediments in the Southern Baltic Sea. The particle size ranges from 0.1 to $2.0 \mathrm{~mm}$ is identified the microplastic, and their microplastic distribution is $77 \%$ in this area. They identified six polymer types are PE-PP, PEST, PVC, PVCE, PAN, and PVA. [233] reported a microplastic concentration of $34 \pm 10$ items $/ \mathrm{kg}$ in the Baltic Sea. The distribution of microplastic is $95 \%$ in this area. [234] deals with microplastic particle $0.07 \pm 0.02$ particles $/ \mathrm{m}^{3}$ in the South Funen Archipelago, Baltic Sea. Microplastic size ranges from 0.3-0.63mm in this region. [235] reported microplastic concentrations of 0-7 particles/ $\mathrm{kg}$ in beach sediments along the German Baltic coast. A microplastic size of $1.05 \mathrm{~mm}$ is identified. However, City discharges, industrial production sites, fishing activity, and tourism are the most likely sources for the highest microplastic concentrations.

\section{Pacific Ocean}

[236] reported that concentration microplastic is $34,039 \pm 25,101$ pieces $/ \mathrm{km}^{2}$ of in the mid-west Pacific Ocean. The microplastic size ranges from 2.5 to $5 \mathrm{~mm}$, and 57.4 \% distribution of microplastic in the study area. They identified several polymer types PE-PP, PS, PP, PEST, PET, and PMMA, are identified using Raman spectra. [237] reported that concentration microplastic is $240 \mathrm{items} / \mathrm{kg}$ in the Western Pacific Ocean. The microplastic size range is $1 \mathrm{~mm}$, and $95 \%$ distribution of microplastic in the study area. The commonly identified polymers types are PP$\mathrm{PE}, \mathrm{PET}$, and polychlorinated biphenyls identified using $\mu$-FTIR. [238] reported that concentration plastic is 0.5 items $\cdot \mathrm{km}^{-2}\left(135 \mathrm{~g} \cdot \mathrm{km}^{-2}\right)$ of in the Pitcairn Islands Marine Reserve. The plastic size range is $5 \mathrm{~cm}$ in the study area. [239] reported that concentration microplastic is $6.2 \times 104$ items $\mathrm{km}^{-2}$ of in the northwestern Pacific Ocean. The microplastic size range is 0.3 and $5 \mathrm{~mm}$, and $60 \%$ distribution of microplastic in the study area. They identified seven polymer types, PEST, PE, PP, PS, PE-PP, PET, and PA, detected using SEM.

\section{Sources of ocean plastic pollution}

China is the largest polluting country in the world (29 percent) (Fig.3). China's population density, which produces over 8.8 million metric tons of mismanaged waste and around 3.53 million metric tons of thrown plastic waste into the ocean, is the leading cause of it contaminating the marine environment. In comparison to China, the rest of Asia accounts for $21 \%$ of plastic pollution. Plastic pollution in the ocean is primarily caused by ten river systems in Asia and Africa. The Yangtze, Yellow, Indus, Hai He, Ganges, Mekong, Amur, and Pearl are the eight river systems in Asia, while the Nile and the Niger are the two in Africa. The United States was ranked in the top twenty countries. Plastic waste accumulates in the maritime environment at a rate of 18 billion pounds each year. European countries cause plastic pollution (19\%), NAFTA countries (18\%), the Middle East/Africa (7\%), and Latin America (4\%). Plastic pollution from landfills accounts for $2 \%$ of all plastic pollution seen on beaches near coastal areas. Indonesia, the Philippines, Vietnam, Sri Lanka, and Egypt are among the top ten nations with poor plastic management, resulting in pollution [240-242]. Microplastics were found in the marine environment all over the world [243, 244]: they were found near dense metropolitan areas, rural areas, and in a variety of marine environmental systems, including beaches [245-246] and deep-sea sediments [27].

\section{Cleaner sea}

\section{National Marine Litter Policy in India}

India releases 600,000 tonnes of plastic waste annually into the oceans. It is necessary to develop the right clean-up technology to overcome marine plastic pollution. To regulate, identify and monitor the source of plastic litter along India's coastal line, the Union Ministry of Earth Sciences took an initiative to clean up the oceans by adopting National Marine Litter Policy and UN Environment's global 'Clean Seas Campaign' in 2018. This policy is about how do we reuse and recycle plastic for a cleaner sea. National marine litter Policy aims to (i) identify the path of plastics from source to sink and promote Reduce, Reuse and Recycle (3R's) concept to create awareness (ii) enumerating the plastic litter in marine sediments, water, and biota along the Indian coast (iii) to build a monitoring, management and mitigation procedures to overcome the impact of Microplastics to clean up oceans. 


\section{Research gap}

Main criteria to tackle research gaps about microplastics in the marine environment.

1. Present an optimal and standardized size description of a microplastic, with additional size specifications for nano - and mesoplastics

2. Improve and adapt systematic, high-throughput microplastic sampling methodologies to effectively correlate the outcomes from various research areas

3. Establish effective methods to identify tiny microplastics and nanoplastics in water columns and sediments

4. Broaden understanding of the nature and behavior of microplastics and their consequences of fragmentation and bio-fouling in the water column

5. Adapt methods to assess microplastic absorption by biota in the food web and extend the usage of sentinel organisms (e.g., Fulmars), and detect the abundance of microplastics in the marine environment.

6. Identify the impact of ingested microplastics (leached plastic additives, waterborne pollutants) on marine biota and recognize its transition within the food chain.

7. Determine the microplastic wastes emitted from wastewater treatment plants (WWTPs) that drains into the rivers.

\section{Conclusion And Future Recommendations}

In this review, 45 papers were collected from the Web of Science during 2013-2020, mainly focused on concentration, identification, size, and distribution of microplastic in different aquatic environments and biota. From previous research, it can be concluded that the sampling and detection of MPs in most research in the marine environment are performed in sediments, biota, and seawater. We have also targeted freshwater habitats such as lakes and rivers in India, which have different types and levels of MPs pollution. A new three-dimensional mathematical modeling analysis is proposed. The level of microplastics is abundant in the areas where the activity of industries and residents were placed near freshwaters. The majority of intakes of microplastics were accumulated in the gut and gastrointestinal tracts of biota. Furthermore, the role of Wastewater treatment plants in emitting microplastics into the nearby aquatic environment should be concentrated, and practical steps to be taken to set up tertiary treatment plants in India to reduce the microplastic pollution from WWTPs. Research gaps in establishing the practical techniques in identifying nanoplastics, the origin of microplastic sources, transportation through various aquatic environments from land-based plastic wastes, absorption of microplastics by biota, and their impact in the food web and food chain still has to be focused predominantly on the future studies.

\section{The following conclusions are derived focused on these reviews}

1. Evaluations of particles by physical diffraction of the light as FTIR and Raman methods have a drawback for small particle scale

2. Clear overview of MPs existence by determining the residence time of MPs within the stomach and gut of biota

3. Identification of MPs engagement with biota to avoid the related complications which could endanger the future health

4. Researchers have to concentrate on defining treatment therapies as the MPs identification is established in reasonable point

5. Future research can be geared at prevention, awareness, and mitigation approaches Cleaner sea to monitor and regulate the sources of plastic pollution along the coastal line

\section{Abbreviations}

ABS Acrylonitrile Butadiene Styrene; ATR-FTIR Attenuated Total Reflectance - Fourier Transform Infrared Spectrometry; CL Cellulose; CP Cellophane; EVA Ethylene-Vinyl Acetate; EVOH Ethylene vinyl alcohol; EVOH Ethylene Vinylalcohol; FTIR Fourier Transform Infrared Spectrometry; GC-ITMS Gas chromatography - Ion trap mass spectrometry; HDPE High-Density Polyethylene; LDPE Low-Density Polyethylene; MMA Polymethyl Methacrylate; NY Nylon; PA Polyamide; PAC Polyacrylic; PAHs Polycyclic Aromatic Hydrocarbons; PAN Polyacrylonitrile; PBAN Polybutadiene acrylonitrile acrylic acid; PBR polybutadiene; PC Polycarbonate; PCU Polycarbonate-Urethane; PD Polydiene; PDMS Polymethylsiloxane; PE Polyethylene; PEA Polyethylene Glycol Adipate; PEI Polyetherimide; PEST Polyester; PET Polyethylene Terephthalate; PEVA Polyethylene-Vinyl Acetate; PI Polyisoprene; PMM Polymelamine; PP Polypropylene; PPA Polyphthalamide; PPF Polyphenylene sulfide; PPO Poly perfluoroethylene oxide; PPS Polyphenylene sulfide; PS Polystyrene; PSF Polysulfide; PSS Polystyrene sulfonate; PTFE Polytetrafluoroethylenes; PU Polyurethane; PVA Polyvinyl Acetate; PVAc Polyvinyl Alcohol; PVAC polyvinyl/vinyl Acetate Copolymer; PVB Polyvinyl Benzoate; PVBP Poly (4-vinylbiphenyl); PVC Polyvinyl Chloride; PVCAP Poly 4-methylcaprolactam; PVCE Polyvinyl Chloride-Ethylene; PVE Polyvinyl Ester; PVF Polyvinyl formal; RPP Resin Polypropylene; RY Rayon; SEM Scanning Electron Microscopy; SEM- 
EDS Scanning Electron Microscopy - Energy Dispersive Spectroscopy; TGA-DSC Thermogravimetric Analysis \& Differential Scanning Calorimetry;

\section{Declarations}

\section{Acknowledgments}

The authors are grateful to thank the Head of the Department, School of Marine Sciences, Department of Oceanography and Coastal Area Studies, Alagappa University, Karaikudi - 630 003, Tamil Nadu, India.

\section{Authors' contributions \\ Karthikeyan Perumal: Conceptualization, Supervision, Investigation, Methodology, Writing - original draft, Writing - review \& editing; Subagunasekar Muthuramalingam: Software; Data analysis; Investigation.}

\section{Funding}

No funding

\section{Availability of data and material}

http://dx.doi.org/10.17632/d6bb655wwg.1

\section{Ethics approval and consent to participate}

Not applicable

\section{Consent for publication}

Not applicable

\section{Competing Interest}

The authors declare that they have no competing interests.

\section{References}

1. Thompson RC (2004) Lost at Sea: Where Is All the Plastic? Science, 304 (5672), 838 -838. https://doi:10.1126/science.1094559

2. Hartmann N, Huffer T, Thompson RC, Hassellov M, Verschoor A, Daugaard AE, Wagner M (2019) Are we speaking the same language? Recommendations for a definition and categorization framework for plastic debris. Environ Sci Technol. 53(3):1039-1047. https://doi:10.1021/acs.est.8b05297

3. Besseling E, Foekema EM, van den Heuvel-Greve MJ, Koelmans AA (2017) The Effect of Microplastic on the Uptake of Chemicals by the Lugworm Arenicola marina (L.) under Environmentally Relevant Exposure Conditions. Environ Sci Technol. 51(15), 87958804. https://doi:10.1021/acs.est.7b02286

4. Cole M, Lindeque P, Halsband C, Galloway TS (2011) Microplastics as contaminants in the marine environment: A review. Mar Pollut Bull. 62 (12), 2588-2597. https://doi.org/10.1016/j.marpolbul.2011.09.025

5. World Economic Forum (2016) The New Plastics Economy Rethinking the future of plastics. 36. http://www3.weforum.org/docs/WEF_The_New_Plastics_Economy.pdf 
6. Lusher AL, Welden NA, Sobral P, Cole M (2017) Sampling, isolating and identifying microplastics ingested by fish and invertebrates. Anal. Methods. 9 (9), 1346-1360. https://doi:10.1039/c6ay02415g

7. UNEP, GRID-Arendal. (2016). Marine litter vital graphics. United Nations Environment Programme and GRID-Arendal. Nairobi and Arendal. Arendal, Norway. 60 p. https://www.grida.no/publications/60

8. Jovanovic B (2017) Ingestion of microplastics by fish and its potential consequences from a physical perspective. Integ Environ Assess Mgmt. 13:510-515

9. Mizraji R, Ahrendt C, Perez-Venegas D, Vargas J, Pulgar J, Aldana M, Ojeda FP, Duarte C, Galbán-Malagon C (2017) Is the feeding type related with the content of microplastics in intertidal fish gut? Mar Pollut Bull. 116:498-500. https://doi:10.1016/j.marpolbul.2017.01.008

10. Ferreira P, Fontea E, Soares ME, Carvalho F, Guilhermino L (2016) Effects of multi-stressors on juveniles of the marine fish Pomatoschistus microps: gold nanoparticles, microplastics and temperature. Aquat Toxicol 170:89103. https://doi:10.1016/j.aquatox.2015.11.011.

11. Welden NAC, Cowie PR (2016a) Environment and gut morphology influence microplastic retention in langoustine, Nephrops norvegicus. Environ Pollut. 214:859-865. https://doi:10.1016/j.envpol.2016.03.067.

12. Welden NAC, Cowie PR (2016b) Long-term microplastic retention causes reduced body condition in the langoustine, Nephrops norvegicus. Environ Pollut. 218:895-900 https://doi:10.1016/j.envpol.2016.08.020.

13. Nadal MA, Alomar C, Deudero S (2016) High levels of microplastic ingestion by the semipelagic fish Bogue Boops boops (L.) around the Balearic Islands. Environ Pollut. 214:517-523. https://doi: 10.1016/j.envpol.2016.04.054.

14. Fonte E, Ferreira P, Guilhermino L (2016) Temperature rise and microplastics interact with the toxicity of theantibiotic cefalexin to juveniles of the common goby (Pomatoschistus microps): postexposure predatory behaviour, acetylcholinesterase activity and lipid peroxidation. Aquat Toxicol. 180:173-185. https://doi:10.1016/j.aquatox.2016.09.015.

15. De Sa LC, Luis LG, Guilhermino L (2015) Effects of microplastics on juveniles of the common goby (Pomatoschistusmicrops): confusion with prey, reduction of the predatory performance and efficiency, and possible influence of developmental conditions. Environ Pollut. 196: 359-362. https://doi.org/10.1016/j.envpol.2014.10.026

16. Carpenter EJ, Smith KL, Harvey GR, Milks HP (1972) On Carpenter and Smith. Science, 177(4043), 8585. https://doi:10.1126/science.177.4043.85

17. Bridson JH, Patel M, Lewis A, Gaw S, Parker K (2020) Microplastic contamination in Auckland (New Zealand) beach sediments. Mar Pollut Bull. 151, 110867. https://doi:10.1016/j.marpolbul.2019.110867

18. Dodsona GZ, Shotorban AK, Hatcher PG, Waggoner DC, Ghosal S, Noffk N (2020) Microplastic fragment and fiber contamination of beach sediments from selected sites in Virginia and North Carolina, USA. Mar Pollut Bull.151, 110869. https://doi.org/10.1016/j.marpolbul.2019.110869

19. Zheng Y, Li J, Cao W, Jiang F, Zhao C, Ding H, Wangc M, Gao F, Sun C (2020) Vertical distribution of microplastics in bay sediment reflecting effects of sedimentation dynamics and anthropogenic activities. Mar Pollut Bull.152, 110885. https://doi:10.1016/j.marpolbul.2020.110885

20. Herrera A, Raymond E, Martinez I, Alvarez S, Canning-Clode J, Gestoso I, Gomez M (2020) First evaluation of neustonic microplastics in the Macaronesian region, NE Atlantic. Mar Pollut Bull.153, 110999. https://doi.org/10.1016/j.marpolbul.2020.110999

21. Chen G, Feng Q, Wang J (2019) Mini-review of microplastics in the atmosphere and their risks to humans. Sci Total Environ. 135504. https://doi:10.1016/j.scitotenv.2019.135504

22. Zhang B, Wu D, Yang X, Teng J, Liu Y, Zhang C, Zhao J, Yin X, You L, Liu Y, Wang Q (2019) Microplastic pollution in the surface sediments collected from Sishili Bay, North Yellow Sea, China. Mar Pollut Bull. 141, 9-15. https://doi:10.1016/j.marpolbul.2019.02.021

23. Constant M, Kerherve P, Mino-Vercellio-Verollet M, Dumontier M, Sanchez Vidal A, Canals M, Heussner S (2019) Beached microplastics in the Northwestern Mediterranean Sea. Mar. Pollut. Bull.142, 263-273. https://doi.org/10.1016/j.marpolbul.2019.03.032

24. Edo C, González-Pleiter M, Leganes F, Fernandez-Pinas F, Rosal R (2020) Fate of microplastics in wastewater treatment plants and their environmental dispersion with effluent and sludge. Environmental Pollution, 259, 113837. https://doi:10.1016/j.envpol.2019.113837

25. Alvarez-Hernandez C, Cairo's C, Lopez-Darias J, Mazzetti E, Hernandez-Sanchez C, Gonzalez-Salamo J, Hernandez-Borges J (2019) Microplastic debris in beaches of Tenerife (Canary Islands, Spain). Mar. Pollut. Bull.146, 26-32. https:// doi: 10.1016/j.marpolbul.2019.05.064

26. Tamminga M, Hengstmann E, Fischer EK (2018) Microplastic analysis in the South Funen Archipelago, Baltic Sea, implementing manta trawling and bulk sampling. Mar Pollut Bull.128, 601-608. https://doi.org/10.1016/j.marpolbul.2018.01.066 
27. Pinon-Colin T, de J, Rodriguez-Jimenez R, Pastrana-Corral MA, Rogel-Hernandez E, Wakida FT (2018) Microplastics on sandy beaches of the Baja California Peninsula, Mexico. Mar Pollut Bull. 131, 63-71. https://doi:10.1016/j.marpolbul.2018.03.055

28. Gray AD, Wertz H, Leads RR, Weinstein JE (2018) Microplastic in two South Carolina Estuaries: Occurrence, distribution, and composition. Mar Pollut Bull. 128, 223-233. https://doi.org/10.1016/j.marpolbul.2018.01.030

29. Wang T, Zou X, Li B, Yao Y, Li J, Hui H, Wang C (2018) Microplastics in a wind farm area: A case study at the Rudong Offshore Wind Farm, Yellow Sea, China. Mar Pollut Bull. 128, 466-474. https://doi:10.1016/j.marpolbul.2018.01.050

30. McWilliams M, Liboiron M, Wiersma Y (2018) Rocky shoreline protocols miss microplastics in marine debris surveys (Fogo Island, Newfoundland and Labrador). Mar Pollut Bull.129 (2), 480-486. https://doi.org/10.1016/j.marpolbul.2017.10.018

31. Bosker T, Guaita L, Behrens P (2018) Microplastic pollution on Caribbean beaches in the Lesser Antilles. Mar Pollut Bull. $133,442-447$. https://doi:10.1016/j.marpolbul.2018.05.060

32. Horton AA, Walton A, Spurgeon DJ, Lahive E, Svendsen C (2017) Microplastics in freshwater and terrestrial environments: evaluating the current understanding to identify the knowledge gaps and future research priorities. Sci Total Environ. 586, 127141. https://doi.org/10.1016/j.scitotenv.2017.01.190

33. Maes T, Jessop R, Wellner N, Haupt K, Mayes AG (2017) A rapid-screening approach to detect and quantify microplastics based on fluorescent tagging with Nile Red. Sci Rep. 7(1). https://doi:10.1038/srep44501

34. Ling SD, Sinclair M, Levi CJ, Reeves SE, Edgar GJ (2017) Ubiquity of microplastics in coastal seafloor sediments. Mar Pollut Bull. 121(12), 104-110. https://doi:10.1016/j.marpolbul.2017.05.038

35. Vaughan R, Turner SD, Rose NL (2017) Microplastics in the sediments of a UK urban lake. Environ Pollut. 229, 1018. https://doi:10.1016/j.envpol.2017.05.057

36. Aytan U, Valente A, Senturk Y, Usta R, Sahin FBE, Mazlum RE, Agirbas E (2016) First evaluation of neustonic microplastics in Black Sea waters. Mar Environ Res. 119, 22-30. https://doi.org/10.1016/j.marenvres.2016.05.009

37. Castillo AB, Al-Maslamani I, Obbard JP (2016) Prevalence of microplastics in the marine waters of Qatar. Mar Pollut Bull. 111(1-2), 260267. https://doi:10.1016/j.marpolbul.2016.06.108

38. Su L, Xue Y, Li L, Yang D, Kolandhasamy P, Li D, Shi H (2016) Microplastics in Taihu Lake, China. Environ Pollut. 216, 711719. https://doi:10.1016/j.envpol.2016.06.036

39. Retama I, Jonathan MP, Shruti VC, Velumani S, Sarkar SK, Roy PD, Rodriguez-Espinosa PF. (2016). Microplastics in tourist beaches of Huatulco Bay, Pacific coast of southern Mexico. Mar. Pollut. Bull. 113(1-2), 530-535. https://doi:10.1016/j.marpolbul.2016.08.053

40. Lusher AL, Tirelli V, O'Connor I, Officer R (2015) Microplastics in Arctic polar waters: the first reported values of particles in surface and sub-surface samples. Sci Rep. 5, 14947. https://doi:10.1038/srep14947

41. Nel HA, Froneman PW (2015) A quantitative analysis of microplastic pollution along the south-eastern coastline of South Africa. Mar Pollut Bull. 101(1), 274-279. https://doi:10.1016/j.marpolbul.2015.09.043

42. Frias JPGL, Otero V, Sobral P (2014) Evidence of microplastics in samples of zooplankton from Portuguese coastal waters. Mar Environ Res. 95, 89-95. https://doi:10.1016/j.marenvres.2014.01.001

43. Song YK, Hong SH, Jang M, Han GM, Shim WJ (2015) Occurrence and Distribution of Microplastics in the Sea Surface Microlayer in Jinhae Bay, South Korea. Arch Environ Contam Toxicol. 69(3), 279-287. https://doi:10.1007/s00244-015-0209-9

44. Zhao S, Zhu L, Wang T, Li D (2014) Suspended microplastics in the surface water of the Yangtze Estuary System, China: First observations on occurrence, distribution. Mar. Pollut. Bull. 86 (1-2), 562-568. https://doi:10.1016/j.marpolbul.2014.06.032

45. Dubaish F, Liebezeit G (2013) Suspended Microplastics and Black Carbon Particles in the Jade System, Southern North Sea. Water Air Soil Pollut. 224(2). https://doi:10.1007/s11270-012-1352-9

46. Vianello A, Boldrin A, Guerriero P, Moschino V, Rella R, Sturaro A, Da Ros L (2013) Microplastic particles in sediments of Lagoon of Venice, Italy: First observations on occurrence, spatial patterns and identification. Estuar Coast Shelf Sci. 130, 5461. https://doi:10.1016/j.ecss.2013.03.022

47. Doyle MJ, Watson W, Bowlin NM, Sheavly SB (2011) Plastic particles in coastal pelagic ecosystems of the Northeast Pacific ocean. Mar Environ Res. 71 (1), 41-52. https://doi:10.1016/j.marenvres.2010.10.001

48. Compa C, Ventero A, Iglesias M, Deudero S (2018) Ingestion of microplastics and natural fibres in Sardina pilchardus (Walbaum, 1792) and Engraulis encrasicolus (Linnaeus, 1758) along the Spanish Mediterranean coast. Mar Pollut Bull. 128, 89-96.

49. Zhao J, Ran W, Teng J, Liu Y, Liu H, Yin X, Wang Q (2018) Microplastic pollution in sediments from the Bohai Sea and the Yellow Sea, China. Sci. Total Environ. 640-641, 637-645. https://doi:10.1016/j.scitotenv.2018.05.346

50. Qu X, Su L, Li H, Liang, M, Shi H (2018) Assessing the relationship between the abundance and properties of microplastics in water and in mussels. Sci Total Environ. 621, 679-686. https://doi:10.1016/j.scitotenv.2017.11.284

Page $15 / 30$ 
51. Ory NC, Sobral P, Ferreira JL, Thiel M (2017) Amberstripe scad Decapterus muroadsi (Carangidae) fish ingest blue microplastics resembling their copepod prey along the coast of Rapa Nui (Easter Island) in the South Pacific subtropical gyre. Sci Total Environ. 586, 430-437. https://doi:10.1016/j.scitotenv.2017.01.175

52. Zhang K, Su J, Xiong X, Wu X, Wu C, Liu J (2016) Microplastic pollution of lakeshore sediments from remote lakes in Tibet plateau, China. Environ Pollut. 219, 450-455. https://doi:10.1016/j.envpol.2016.05.048

53. Nadal MA, Alomar C, Deudero S (2016) High levels of microplastic ingestion by the semipelagic fish bogue Boops boops (L.) around the Balearic Islands. Environ Pollut. 214, 517-523. https://doi:10.1016/j.envpol.2016.04.054

54. Bellas J, Martinez-Armental J, Martínez-Camara A, Besada V, Martinez-Gomez C (2016) Ingestion of microplastics by demersal fish from the Spanish Atlantic and Mediterranean coasts. Mar Pollut Bull. 109(1), 55-60. https://doi:10.1016/j.marpolbul.2016.06.026

55. Green DS (2016) Effects of microplastics on European flat oysters, Ostrea edulis and their associated benthic communities. Environ Pollut. 216, 95-103. https://doi:10.1016/j.envpol.2016.05.043

56. James K, Vasant K, Padua S, Gopinath V, Abilash KS, Jeyabaskaran R, Akhil Babu, John S (2020) An assessment of microplastics in the ecosystem and selected commercially important fishes off Kochi, south eastern Arabian Sea, India. Mar Pollut Bull. 154, 111027. https://doi:10.1016/j.marpolbul.2020.111027

57. Daniel DB, Ashraf PM, Thomas SN (2020) Abundance, characteristics and seasonal variation of microplastics in Indian white shrimps (Fenneropenaeus indicus) from coastal waters off Cochin, Kerala, India. Sci Total Environ. https://doi.org/10.1016/j.scitotenv.2020.139839

58. Dowarah K, Patchaiyappan A, Thirunavukkarasu C, Jayakumar S, Devipriya SP (2020) Quantification of microplastics using Nile Red in two bivalve species Perna viridis and Meretrix from three estuaries in Pondicherry, India and microplastic uptake by local communities through bivalve diet. Mar Pollut Bull., 153, 110982. https://doi:10.1016/j.marpolbul.2020.110982

59. Narmatha Sathish M, Immaculate Jeyasanta K, Patterson J (2020) Monitoring of microplastics in the clam Donax cuneatus and its habitat in Tuticorin coast of Gulf of Mannar (GoM), India. Environ Pollut. 115219. https://doi:10.1016/j.envpol.2020.115219

60. Sathish N, Jeyasanta I, Patterson J (2020a) Occurrence of microplastics in epipelagic and mesopelagic fishes from Tuticorin, Southeast coast of India. Sci Total Environ. 137614. https://doi:10.1016/j.scitotenv.2020.137614

61. Devi SS, Sreedevi AV, Kumar AB (2020) First report of microplastic ingestion by the alien fish Pirapitinga (Piaractus brachypomus) in the Ramsar site Vembanad Lake, south India. Mar Pollut Bull. 160, 111637. https://doi:10.1016/j.marpolbul.2020.111637

62. Karuppasamy PK, Ravi A, Vasudevan L, Elangovan MP, Dyana Mary P, Vincent SGT, Palanisami T (2020) Baseline survey of micro and mesoplastics in the gastrointestinal tract of commercial fish from Southeast coast of the Bay of Bengal. Mar Pollut Bull. 153, 110974. https://doi:10.1016/j.marpolbul.2020.110974

63. Naidu SA (2019) Preliminary study and first evidence of presence of microplastics and colorants in green mussel, Perna viridis (Linnaeus, 1758), from southeast coast of India. Mar. Pollut. Bull. 140, 416-422. https://doi.org/10.1016/j.marpolbul.2019. 01.024

64. Patterson J, Jeyasanta KI, Sathish N, Booth AM, Edward JKP (2019) Profiling microplastics in the Indian edible oyster, Magallana bilineata collected from the Tuticorin coast, Gulf of Mannar, Southeastern India. Sci Total Environ. https://doi:10.1016/j.scitotenv.2019.07.063

65. Kumar VE, Ravikumar G, Jeyasanta KI (2018) Occurrence of microplastics in fishes from two landing sites in Tuticorin, South east coast of India. Mar Pollut Bull. 135, 889-894. https://doi:10.1016/j.marpolbul.2018.08.023

66. Naidu SA, Ranga Rao V, Ramu K (2018) Microplastics in the benthic invertebrates from the coastal waters of Kochi, Southeastern Arabian Sea. Environ Geochem Health. 40(4), 1377-1383. https://doi:10.1007/s10653-017-0062-z

67. Raha U, Kumar BR, Sarkar SK (2021) Policy Framework for Mitigating Land-Based Marine Plastic Pollution in the Gangetic Delta Region of Bay of Bengal-A Review. J Clean Prod. 278. 123409. https://doi.org/10.1016/j.jclepro.2020.123409

68. Manickavasagam S, Kumar S, Kumar K, Rathi Bhuvaneswari G, Paul T, Shukla SP (2020) Quantitative assessment of influx and efflux of marine debris in a water channel of South Juhu creek, Mumbai, India. Reg. Stud Mar Sci. 34,

101095. https://doi:10.1016/j.rsma.2020.101095

69. Vidyasakar A, Krishnakumar S, Kasilingam K, Neelavannan K, Bharathi VA, Godson PS, Magesh NS (2020) Characterization and distribution of microplastics and plastic debris along Silver Beach, Southern India. Mar Pollut Bull., 158, 111421. https://doi:10.1016/j.marpolbul.2020.111421

70. Jeyasanta Kl, Sathish N, Patterson J, Edward JKP (2020) Macro-, meso- and microplastic debris in the beaches of Tuticorin district, Southeast coast of India. Mar Pollut Bull. 154, 111055. https://doi:10.1016/j.marpolbul.2020.111055

71. Patterson J, Jeyasanta K, Sathish N, Edward JKP, Booth AM (2020) Microplastic and heavy metal distributions in an Indian coral reef ecosystem. Sci Total Environ. 140706. https://doi:10.1016/j.scitotenv.2020.140706

Page $16 / 30$ 
72. Suman TY, Li, WG, Alif S, Faris VRP, Amarnath DJ, Ma JG, Pei DS (2020) Characterization of petroleum-based plastics and their absorbed trace metals from the sediments of the Marina Beach in Chennai, India. Environ Sci Eur. 32, 110. https://doi.org/10.1186/s12302-020-00388-5

73. Patchaiyappan A, Ahmed SZ, Dowarah K, Jayakumar S, Devipriya SP (2020) Occurrence, distribution and composition of microplastics in the sediments of South Andaman beaches, Mar Pollut Bull. 156, 111227. https://doi.org/10.1016/j.marpolbul.2020.111227

74. Selvam K, Xavier KAM, Shivakrishna A, Bhutia TP, Kamat S, Shenoy L (2020) Abundance, composition and sources of marine debris trawled-up in the fishing grounds along the North-East Arabian coast. Sci Total Environ. 141771. doi:10.1016/j.scitotenv.2020.141771

75. Sundar S, Chokkalingam L, Roy PD, Usha T (2020) Estimation of microplastics in sediments at the southernmost coast of India (Kanyakumari). Environ Sci Pollut Res. 28, 18495-18500. https://doi:10.1007/s11356-020-10333-x

76. Robin RS, Karthik R, Purvaja R, Ganguly D, Anandavelu I, Mugilarasan M, Ramesh R (2019) Holistic assessment of microplastics in various coastal environmental matrices, southwest coast of India. Sci Total Environ. 134947. https://doi:10.1016/j.scitotenv.2019.134947

77. Sathish N, Jeyasanta KI, Patterson J (2019) Abundance, characteristics and surface degradation features of microplastics in beach sediments of five coastal areas in Tamil Nadu, India. Mar Pollut Bull., 142, 112-118. https://doi:10.1016/j.marpolbul.2019.03.037

78. Tiwari M, Rathod TD, Ajmal PY, Bhangare RC, Sahu SK (2019) Distribution and characterization of microplastics in beach sand from three different Indian coastal environments. Mar Pollut Bull., 140, 262-273. https://doi:10.1016/j.marpolbul.2019.01.055

79. Daniel DB, Thomas SN, Thomson KT (2019) Assessment of fishing-related plastic debris along the beaches in Kerala Coast, India. Mar Pollut Bull., 110696. https://doi:10.1016/j.marpolbul.2019.110696

80. Ashwini SK, Varghese GK (2019) Environmental forensic analysis of the microplastic pollution at "Nattika" Beach, Kerala Coast, India. Environ Forensics. 1-16. https://doi:10.1080/15275922.2019.1693442

81. Arun Kumar A, Sivakumar R, Sai Rutwik Y, Nishanth T, Revanth V, Kumar S (2019) Marine Debris in India: Quantifying Type and Abundance of Beach Litter along Chennai, East Coast of India. Lecture Notes on Multidisciplinary Industrial Engineering, 217230. https://doi:10.1007/978-981-13-6148-7_23

82. Dowarah K, Devipriya SP (2019) Microplastic prevalence in the beaches of Puducherry, India and its correlation with fishing and tourism/recreational activities. Mar Pollut Bull. 148, 123-133. https://doi:10.1016/j.marpolbul.2019.07.066

83. Karthik R, Robin RS, Purvaja R, Ganguly D, Anandavelu I, Raghuraman R, Ramesh R (2018) Microplastics along the beaches of southeast coast of India. Sci Total Environ. 645, 1388-1399. https://doi:10.1016/j.scitotenv.2018.07.242

84. Vidyasakar A, Neelavannan K, Krishnakumar S, Prabaharan G, Sathiyabama Alias Priyanka T, Magesh NS, Srinivasalu S (2018) Macrodebris and microplastic distribution in the beaches of Rameswaram Coral Island, Gulf of Mannar, Southeast coast of India: A first report. Mar Pollut Bull., 137, 610-616. https://doi:10.1016/j.marpolbul.2018.11.007

85. Krishnakumar S, Srinivasalu S, Saravanan P, Vidyasakar A, Magesh NS (2018) A preliminary study on coastal debris in Nallathanni Island, Gulf of Mannar Biosphere Reserve, Southeast coast of India. Mar Pollut Bull. 131, 547-551. https://doi:10.1016/j.marpolbul.2018.04.026

86. Sruthy S, Ramasamy EV (2017) Microplastic pollution in Vembanad Lake, Kerala, India: The first report of microplastics in lake and estuarine sediments in India. Environ Pollut. 222, 315-322. https://doi:10.1016/j.envpol.2016.12.038

87. Arun Kumar A, Sivakumar R, Sai Rutwik Reddy Y, Bhagya Raja MV, Nishanth T, Revanth V (2016) Preliminary study on marine debris pollution along Marina beach, Chennai, India. Reg Stud Mar Sci. 5, 35-40. https://doi:10.1016/j.rsma.2016.01.002

88. Veerasingam S, Saha, M, Suneel V, Vethamony P, Rodrigues AC, Bhattacharyya S, Naik BG (2016) Characteristics, seasonal distribution and surface degradation features of microplastic pellets along the Goa coast, India. Chemosphere, 159, 496505. https://doi:10.1016/j.chemosphere.2016.06.056

89. Jayasiri HB, Purushothaman CS, Vennila A (2015) Bimonthly variability of persistent organochlorines in plastic pellets from four beaches in Mumbai coast, India. Environ Monit Assess. 187(7). https://doi:10.1007/s10661-015-4531-5

90. Jayasiri HB, Purushothaman CS, Vennila A (2013a) Quantitative analysis of plastic debris on recreational beaches in Mumbai, India. Mar Pollut Bull. 77(1-2), 107-112. https://doi:10.1016/j.marpolbul.2013.10.024

91. Jayasiri HB, Purushothaman CS, Vennila A (2013b) Plastic litter accumulation on high-water strandline of urban beaches in Mumbai, India. Environ Monit Assess. 185(9), 7709-7719. https://doi:10.1007/s10661-013-3129-z

92. Selvam S, Manisha A, Venkatramanan S, Chung SY, Paramasivam CR, Singaraja C (2020) Microplastic presence in commercial marine sea salts: A baseline study along Tuticorin Coastal salt pan stations, Gulf of Mannar, South India. Mar Pollut Bull. 150, 110675. https://doi:10.1016/j.marpolbul.2019.110675 
93. Sathish MN, Jeyasanta I, Patterson J (2020b) Microplastics in Salt of Tuticorin, Southeast Coast of India. Arch. Environ. Contam. Toxicol. https://doi:10.1007/s00244-020-00731-0

94. Seth CK, Shriwastav A (2018) Contamination of Indian sea salts with microplastics and a potential prevention strategy. Environ Sci Pollut Res. https://doi:10.1007/s11356-018-3028-5

95. Patti TB, Fobert EK, Reeves SE (2020) Spatial distribution of microplastics around an inhabited coral island in the Maldives, Indian Ocean, Sci Total Environ. 141263. https://doi.org/10.1016/j.scitotenv

96. Goswami P, Vinithkumar NV, Dharani G (2020) First evidence of microplastics bioaccumulation by marine organisms in the Port Blair Bay, Andaman Islands. Mar. Pollut. Bull. 155. 111163. https://doi.org/10.1016/j.marpolbul.2020.111163

97. Imhof HK, Sigl R, Brauer E, Feyl S, Giesemann P, Klink S, Laforsch C (2017) Spatial and temporal variation of macro-, meso- and microplastic abundance on a remote coral island of the Maldives, Indian Ocean. Mar. Pollut. Bull., 116(1-2), 340-347. https://doi:10.1016/j.marpolbul.2017.01.010

98. Amrutha K, Warrier AK (2020) The first report on the source-to-sink characterization of microplastic pollution from a riverine environment in tropical India. Sci Total Environ. 140377. https://doi:10.1016/j.scitotenv.2020.140377

99. Sarkar DJ, Sarkar SD, Das BK, Manna RK, Behera BK, Samanta S (2019) Spatial distribution of meso and microplastics in the sediments of river Ganga at eastern India. Sci Total Environ. 133712. https://doi:10.1016/j.scitotenv.2019.133712

100. Bharath K, Srinivasalu M, Usha S, Ramamoorthy N, Kalam SA, Anbalagan N, Sujatha S, Alagarasan C (2020) Microplastics as an emerging threat to the freshwater ecosystems of Veeranam lake in South India: A Multidimensional Approach. Chemosphere, 128502. https://doi:10.1016/j.chemosphere.2020.128502

101. Gopinath K, Seshachalam S, Neelavannan K, Anburaj V, Rachel M, Ravi S, Achyuthan H (2020) Quantification of microplastic in Red Hills Lake of Chennai city, Tamil Nadu, India. Environ. Sci. Pollut. Res. https://doi:10.1007/s11356-020-09622-2

102. Zhang F, Yao C, Xu J, Zhu L, Peng G, Li D (2020) Composition, spatial distribution and sources of plastic litter on the East China Sea floor. Sci Total Environ.140525. https://doi:10.1016/j.scitotenv.2020.140525

103. Harris PT (2020) The fate of microplastic in marine sedimentary environments: A review and synthesis. Mar Pollut Bull.158, 111398. https://doi:10.1016/j.marpolbul.2020.111398

104. Peng L, Fu D, Qi H, Lan CQ, Yu H, Ge C (2020) Micro- and nano-plastics in marine environment: Source, distribution and threats - A review. Sci Total Environ.134254. doi:10.1016/j.scitotenv.2019.134254

105. Akdogan Z, Guven B (2019) Microplastics in the Environment: A Critical Review of Current Understanding and Identification of Future Research Needs. Environ Pollut. 113011. https://doi:10.1016/j.envpol.2019.113011

106. Gago J, Carretero O, Filgueiras AV, Vinas L. (2018). Synthetic microfibers in the marine environment: A review on their occurrence in seawater and sediments. Mar Pollut Bull.127, 365-376. https://doi.org/10.1016/j.marpolbul.2017.11.070

107. Auta HS, Emenike C, Fauziah S (2017) Distribution and importance of microplastics in the marine environment: A review of the sources, fate, effects, and potential solutions. Environ Int.102, 165-176. https://doi.org/10.1016/j.envint.2017.02.013

108. Avio CG, Cardelli LR, Gorbi S, Pellegrini D, Regoli F (2017) Microplastics pollution after the removal of the Costa Concordia wreck: First evidences from a biomonitoring case study. Environ Pollut. 227, 207-214. doi:10.1016/j.envpol.2017.04.066

109. Li J, Qu X, Su L, Zhang W, Yang D, Kolandhasamy P, Shi H (2016) Microplastics in mussels along the coastal waters of China. Environ Pollut. 214, 177-184. https://doi:10.1016/j.envpol.2016.04.012

110. Barboza LGA, Gimenez BCG (2015) Microplastics in the marine environment: Current trends and future perspectives. Mar Pollut Bull. 97(1-2), 5-12. https://doi.org/10.1016/j.marpolbul.2015.06.008

111. Andrady AL (2011) Microplastics in the marine environment. Mar Pollut Bull. 62(8), 15961605. https://doi.org/10.1016/j.marpolbul.2011.05.030

112. Ajith N, Arumugam S, Parthasarathy S, Manupoori S, Janakiraman S (2020) Global distribution of microplastics and its impact on marine environment - a review. Environ Sci Pollut Res. 27, 25970-25986. https://doi.org/10.1007/s11356-020-09015-5

113. Anbumani S, Kakkar P (2018) Ecotoxicological effects of microplastics on biota: a review. Environ Sci Pollut Res. 25(15), 14373-14396. https://doi:10.1007/s11356-018-1999-x

114. Rezania S, Park J, Md Din MF, Mat Taib S, Talaiekhozani A, Kumar Yadav K, Kamyab H (2018) Microplastics pollution in different aquatic environments and biota: A review of recent studies. Mar Pollut Bull.133, 191-208. doi:10.1016/j.marpolbul.2018.05.022

115. Wesch C, Bredimus K, Paulus M, Klein R (2016) Towards the suitable monitoring of ingestion of microplastics by marine biota: A review. Environ Pollut. 218, 1200-1208. https://doi:10.1016/j.envpol.2016.08.076

116. Ivar do Sul JA, Costa MF (2014) The present and future of microplastic pollution in the marine environment. Environ Pollut. 185, 352364. doi:10.1016/j.envpol.2013.10.036

Page $18 / 30$ 
117. Guo X, Wang J (2019) The chemical behaviors of microplastics in marine environment: A review. Mar Pollut Bull.142, 114. https://doi.org/10.1016/j.marpolbul.2019.03.019

118. Wright SL, Thompson RC, Galloway TS (2013) The physical impacts of microplastics on marine organisms: A review. Environ Pollut. 178, 483-492. https://doi:10.1016/j.envpol.2013.02.031

119. Wang J, Peng J, Tan Z, Gao Y, Zhan Z, Chen Q, Cai L (2017) Microplastics in the surface sediments from the Beijiang River littoral zone: Composition, abundance, surface textures and interaction with heavy metals. Chemosphere, 171, 248258. https://doi:10.1016/j.chemosphere.2016.12.074

120. Uddin S, Fowler SW, Saeed T (2020) Microplastic particles in the Persian/Arabian Gulf - A review on sampling and identification. Mar Pollut Bull. 154, 111100. https://doi.org/10.1016/j.marpolbul.2020.111100

121. Stock F, Kochleus C, Bänsch-Baltruschat B, Brennholt N, Reifferscheid G (2019) Sampling techniques and preparation methods for microplastic analyses in the aquatic environment - a review. Trends Anal Chem. https://doi:10.1016/j.trac.2019.01.014

122. Mai L, Bao LJ, Shi L, Wong CS, Zeng EY (2018) A review of methods for measuring microplastics in aquatic environments. Environ Sci Pollut Res. 25(12), 11319-11332. https://doi:10.1007/s11356-018-1692-0

123. Hanvey JS, Lewis PJ, Lavers JL, Crosbie ND, De KP, Clarke BO, Pete PET (2017) A review of analytical techniques for quantifying microplastics in sediments. Anal Methods. 1369-1383. https://doi:10.1039/c6ay02707e.

124. Hidalgo-Ruz V, Gutow L, Thompson RC, Thiel M (2012) Microplastics in the Marine Environment: A Review of the Methods Used for Identification and Quantification. Environ Sci Technol. 46(6), 3060-3075. https://doi:10.1021/es2031505

125. Ryan PG, Moore CJ, van Franeker JA, Moloney CL (2009) Monitoring the abundance of plastic debris in the marine environment. Philos. Trans. R. Soc., B 364, 1999-2012.

126. Duis K, Coors A (2016) Microplastics in the aquatic and terrestrial environment: sources (with a specific focus on personal care products), fate and effects. Environ Sci Eur. 28 (2). http://dx.doi.org/10.1186/s12302-015-0069-y

127. Wagner M, Scherer C, Alvarez-Munoz D, Brennholt N, Bourrain X, Buchinger S, Fries E, Grosbois C, Klasmeier J, Marti T, Rodriguez-Mozaz S, Urbatzka R, Vethaak AD, Winther-Nielsen M, Reifferscheid G (2014) Microplastics in freshwater ecosystems: what we know and what we need to know. Environ Sci Eur. 26:12. http://dx. doi.org/10.1186/s12302-014-0012-7.

128. Beltifa A, Belaid A, Vincenzo LT, Monia M, Hedi MB, Giuseppa DB (2018) Preliminary evaluation of plasticizer and BPA in Tunisian cosmetics and investigation of hazards on human skin cells. Int J Environ Health Res. 1-11.

https://doi:10.1080/09603123.2018.1489528

129. GESAMP (2016) Sources, fate and effects of microplastics in the marine environment: part two of a global assessment. (Kershaw, P.J., and Rochman, C.M., eds). (IMO/FAO/UNESCO-IOC/UNIDO/WMO/IAEA/UN/ UNEP/UNDP Joint Group of Experts on the Scientific Aspects of Marine Environmental Protection). Rep. Stud. GESAMP. 93, 220.

130. Alomar C, Estarellas F, Deudero S (2016) Microplastics in the Mediterranean Sea: Deposition in coastal shallow sediments, spatial variation and preferential grain size. Mar. Environ. Res. 115, 1-10. https://doi: 10.1016/j.marenvres.2016.01.005

131. Castaneda RA, Avlijas S, Simard MA, Ricciardi, A (2014) Microplastic pollution in St. Lawrence River sediments. Can. J. Fish. Aquat. Sci. 70:1767-1771. http://dx.doi.org/ 10.1139/cjfas-2014-0281.

132. Costa M, Ivar do Sul J, Silva-Cavalcanti J, Araujo M, Spengler A, Tourinho P (2010) On the importance of size of plastic fragments and pellets on the strandline: a snapshot of a Brazilian beach. Environ Monit Assess. 168, 299-304.

133. GESAMP (2014) Microplastics in the ocean - a global assessment. GESAMP -IOC, Paris (France); IMO/FAO/IOC/WMO/UNIDO/IAEA/UN/UNEP. Joint Group of Experts on the Scientific Aspects of Marine Environmental Protection 2014.

134. Barnes DK, Galgani F, Thompson RC, Barlaz M (2009) Accumulation and fragmentation of plastic debris in global environments. Philos. Trans. R. Soc. Lond. B Biol. Sci. 364, 1985-1998.

135. Rios LM, Moore C, Jones PR (2007) Persistent organic pollutants carried by synthetic polymers in the ocean environment. Mar. Pollut. Bull. 54, 1230-1237.

136. Morris C (2015) Marine Litter, Green Facts: Facts on Health and the Environment. pp. 2001-2015

137. Grossman E (2015) How plastics from your clothes can end up in your fish. TIME, USA

138. Gies EA, LeNoble JL, Noel M, Etemadifar A, Bishay F, Hall ER, Ross PS (2018) Retention of microplastic in a major secondary wastewater treatment plant in Vancouver, Canada. Mar Pollut Bull. 133, 553 -561. https://doi.org/10.1016/j.marpolbul.2018.06.006

139. Talvitie J, Mikola A, Setala O, Heinonen M, Koistinen A (2017) How well is microlitter purified from wastewater? A detailed study on the stepwise removal of microlitter in a tertiary level wastewater treatment plant. Water Research, 109, 164-172. https://doi.org/10.

1016/j.watres.2016.11.046

Page 19/30 
140. Lawale D, Jelkie N (2017) Knowledge Paper on Plastic Industry for Infrastructure. 3rd National Conference of Sustainable Infrastructure with Plastics. Organized by FICCI. 35p. http://ficci.in/study -page.asp?spid=20872\&sectorid=88

141. Rodrigues MO, Abrantes N, Gonçalves FJM, Nogueira H, Marques JC, Goncalves AMM (2018) Spatial and temporal distribution of microplastics in water and sediments of a freshwater system (Antua River, Portugal). Sci Total Environ. 633, 15491559. https://doi:10.1016/j.scitotenv.2018.03.233

142. Liu P, Zhan X, Wu X, Li J, Wang H, Gao S (2019) Effect of weathering on environmental behavior of microplastics: Properties, sorption and potential risks. Chemosphere, 125193. https://doi:10.1016/j.chemosphere.2019.125193

143. Lin L, Zuo LZ, Peng JP, Cai LQ, Fok L, Yan Y, Xu XR (2018) Occurrence and distribution of microplastics in an urban river: A case study in the Pearl River along Guangzhou City, China. Sci Total Environ. 644, 375-381. https://doi:10.1016/j.scitotenv.2018.06.327

144. Yan M, Nie H, Xu K, He Y, Hu Y, Huang Y, Wang J (2019) Microplastic abundance, distribution and composition in the Pearl River along Guangzhou city and Pearl River estuary, China. Chemosphere, 217, 879-886. https://doi:10.1016/j.chemosphere.2018.11.093

145. Klein S, Worch E, Knepper TP (2015) Occurrence and Spatial Distribution of Microplastics in River Shore Sediments of the Rhine-Main Area in Germany. Environ. Sci. Technol. 49(10), 6070-6076. https://doi:10.1021/acs.est.5b00492

146. Nel HA, Dalu T, Wasserman RJ (2018) Sinks and sources: Assessing microplastic abundance in river sediment and deposit feeders in an Austral temperate urban river system. Sci Total Environ. 612, 950-956. https://doi:10.1016/j.scitotenv.2017.08.298

147. Kataoka T, Nihei Y, Kudou K, Hinata H (2018) Assessment of the sources and inflow processes of microplastics in the river environments of Japan. Environ Pollut. https://doi:10.1016/j.envpol.2018.10.111

148. Bordos G, Urbanyi B, Micsinai A, Kriszt B, Palotai Z, Szabo I, Szoboszlay S (2018) Identification of microplastics in fish ponds and natural freshwater environments of the Carpathian basin, Europe. Chemosphere. https://doi:10.1016/j.chemosphere.2018.10.110

149. Woodall LC, Gwinnett C, Packer M, Thompson RC, Robinson LF, Paterson GL (2015) Using a forensic science approach to minimize environmental contamination and to identify microfibres in marine sediments. Mar Pollut Bull. 95, 40-46. https://doi:

10.1016/j.marpolbul.2015.04.044

150. Veerasingam S, Mugilarasan M, Venkatachalapathy R, Vethamony $P$ (2016) Influence of 2015 flood on the distribution and occurrence of microplastic pellets along the Chennai coast, India. Mar Pollut Bull. 109(1), 196-204. https://doi:10.1016/j.marpolbul.2016.05.082

151. Aytan U, Valente A, Senturk Y, Usta R, Esensoy Sahin FB, Mazlum RE, Agirbas E (2016) First evaluation of neustonic microplastics in Black Sea waters. Mar Environ Res. 119, 22-30. https://doi:10.1016/j.marenvres.2016.05.009

152. Karami A, Golieskardi A, Choo CK, Larat V, Galloway TS, Salamatinia B (2017) The presence of microplastics in commercial salts from different countries. Sci Rep 7 (46173), 1-9. https://doi:10.1038/srep46173

153. Jambeck JR, Geyer R, Wilcox C, Siegler TR, Perryman M, Andrady A, Narayan R, Law KL (2015) Plastic waste inputs from land into the ocean. Science. $347,768-771$.

154. Mason S, Kammin L, Eriksen M, Aleid G, Box C, Williamson N (2017) Pelagic plastic pollution within the surface waters of Lake Michigan, USA. J. Gt. Lakes Res. 753-759.

155. Schirinzi GF, Perez-Pomeda I, Sanchis J, Rossini C, Farre M, Barcelo D (2017) Cytotoxic effects of commonly used nanomaterials and microplastics on cerebral and epithelial cells. Environ Res. 67, 579-587, https://doi.org/10.1016/j.envres.2017.08.043

156. Iniguez ME, Conesa JA, Fullana A (2017) Microplastics in Spanish Table Salt. Sci Rep. 7(1). https://doi:10.1038/s41598-017-09128-x

157. Yang D, Shi H, Li L, Li J, Jabeen K, Kolandhasamy P (2015) Microplastic Pollution in Table Salts from China. Environ Sci Technol. 49(22), 13622-13627. https://doi:10.1021/acs.est.5b03163

158. Yu M, van der Ploeg M, Lwanga EH, Yang X, Zhang S, Ma X, Geissen V (2019) Leaching of microplastics by preferential flow in earthworm (Lumbricus terrestris) burrows. Environmental Chemistry. https://doi:10.1071/en18161

159. Huerta LE, Mendoza VJ, Ku Quej V, Chi JLA, Sanchez Del Cid L, Chi C, Escalona Segura G, Gertsen H, Salanki T, van der Ploeg M, Koelmans AA, Geissen V (2017) Field evidence for transfer of plastic debris along a terrestrial food chain. Sci Rep. 7, 14071. https://doi:10. 1038/S41598-017-14588-2

160. Maas S, Daphi D, Lehmann A, Rillig MC (2017) Transport of microplastics by two collembolan species. Environ Pollut. $225,456-459$. https://doi:10.1016/J.ENVPOL.2017.03.009

161. Rillig MC, Ziersch L, Hempel S (2017) Microplastic transport in soil by earthworms. Sci Rep. 7, 1362. https://doi:10.1038/S41598-01701594-7

162. Prata JC (2018) Airborne microplastics: Consequences to human health? Environ Pollut. 234, 115126. https://doi:10.1016/j.envpol.2017.11.043

163. Bouwmeester H, Hollman PCH, Peters RJB (2015) Potential Health Impact of Environmentally Released Micro- and Nanoplastics in the Human Food Production Chain: Experiences from Nanotoxicology. Environ Sci Technol. 49(15), 8932-

Page 20/30 
8947. https://doi:10.1021/acs.est.5b01090

164. Derraik JG (2002) The pollution of the marine environment by plastic debris: a review. Mar Pollut Bull. 44(9), 842852. https://doi:10.1016/s0025-326x(02)00220-5

165. Obbard RW, Sadri S, Wong YQ, Khitun AA, Baker I, Thompson RC (2014) Global warming releases microplastic legacy frozen in Arctic Sea ice. Earth's Future, 2(6), 315-320. https://doi:10.1002/2014ef000240

166. Zhang K, Gong W, Lv J, Xiong X, Wu C (2015) Accumulation of floating microplastics behind the Three Gorges Dam. Environ Pollut. 204, 117-123. https://doi:10.1016/j.envpol.2015.04.023

167. Dris R, Gasperi J, Mirande C, Mandin C, Guerrouache M, Langlois V, Tassin B (2017) A first overview of textile fibers, including microplastics, in indoor and outdoor environments. Environ Pollut. 221, 453-458. https://doi:10.1016/j.envpol.2016.12.013

168. Cai L, Wang J, Peng J, Tan Z, Zhan Z, Tan X, Chen Q (2017) Characteristic of microplastics in the atmospheric fallout from Dongguan city, China: preliminary research and first evidence. Environ Sci Pollut Res. 24(32), 24928-24935. https://doi:10.1007/s11356-017-0116$x$

169. Bergmann M, Mutzel S, Primpke S, Tekman MB, Trachsel J, Gerdts G (2019) White and wonderful? Microplastics prevail in snow from the Alps to the Arctic. Sci Adv. 5(8), eaax1157. doi:10.1126/sciadv.aax1157

170. Li J, Yang D, Li L, Jabeen K, Shi H (2015) Microplastics in commercial bivalves from China. Environ Pollut. 207, 190195. https://doi:10.1016/j.envpol.2015.09.018

171. Moore CJ (2008) Synthetic polymers in the marine environment: A rapidly increasing, long-term threat. Environ Res. 108(2), 131139. https://doi:10.1016/j.envres.2008.07.025

172. Lei L, Wu S, Lu S, Liu M, Song Y, Fu Z, Shi H, Raley-Susman KM, He D (2018) Microplastic particles cause intestinal damage and other adverse effects in zebrafish Danio rerio and nematode Caenorhabditis elegans. Sci Total Environ. 619-620, 1-8. https://doi:10.1016/j.scitotenv.2017.11.103

173. Yu X, Peng J, Wang J, Wang K, Bao S (2016) Occurrence of microplastics in the beach sand of the Chinese inner sea: the Bohai Sea. Environ Pollut. 214, 722-730. https://doi:10.1016/j.envpol.2016.04.080

174. Lots FAE, Behrens P, Vijver MG, Horton AA, Bosker T (2017) A large-scale investigation of microplastic contamination: Abundance and characteristics of microplastics in European beach sediment. Mar. Pollut. Bull. 123(1-2), 219226. https://doi:10.1016/j.marpolbul.2017.08.057

175. Hengstmann E, Tamminga M, vom Bruch C, Fischer EK (2018) Microplastic in beach sediments of the Isle of Rugen (Baltic Sea) Implementing a novel glass elutriation column. Mar Pollut Bull. 126, 263-274. doi:10.1016/j.marpolbul.2017.11.010

176. Zhang GS, Liu YF (2018) The distribution of microplastics in soil aggregate fractions in southwestern China. Sci. Total Environ. 642, 1220. https://doi:10.1016/j.scitotenv.2018.06.004

177. Zheng Y, Li J, Cao W, Jiang F, Zhao C, Ding H, Wangc M, Gao F, Sun C (2020) Vertical distribution of microplastics in bay sediment reflecting effects of sedimentation dynamics and anthropogenic activities. Mar Pollut Bull.152, 110885. https://doi:10.1016/j.marpolbul.2020.110885

178. Zhang F, Yao C, Xu J, Zhu L, Peng G, Li D (2020) Composition, spatial distribution and sources of plastic litter on the East China Sea floor. Sci Total Environ.140525. https://doi:10.1016/j.scitotenv.2020.140525

179. Sui Q, Zhang L, Xia B, Chen B, Sun X, Zhu L, Wang R, Qu K (2020) Spatiotemporal distribution, source identification and inventory of microplastics in surface sediments from Sanggou Bay, China. Sci Total Environ.138064. https://doi:10.1016/j.scitotenv.2020.138064

180. Tan F, Yang H, Xu X, Fang Z, Xu H, Shi Q, Zhang X, Wang G, Lin L, Zhou S, Huang L, Li H (2020) Microplastic pollution around remote uninhabited coral reefs of Nansha Islands, South China Sea. Sci Total Environ.138383. https://doi:10.1016/j.scitotenv.2020.138383

181. Teng J, Zhao J, Zhang C, Cheng B, Koelmans AA, Wu D, Gao M, Sun X, Liu Y, Wang Q (2020) A systems analysis of microplastic pollution in Laizhou Bay, China. Sci Total Environ.140815. https://doi:10.1016/j.scitotenv.2020.140815

182. Wang T, Hu M, Song L, Yu J, Liu R, Wang S, Wang Z, Sokolova MI, Huang W, Wang Y (2020) Coastal zone use influences the spatial distribution of microplastics in Hangzhou Bay, China. Environ Pollut. 115137. https://doi:10.1016/j.envpol.2020.115137

183. Wang Q, Shan E, Zhang B, Teng J, Wu D, Yang X, Zhang Chen, Zhang W, Sun X, Zhao J (2020) Microplastic pollution in intertidal sediments along the coastline of China. Environ Pollut. 114428. https://doi:10.1016/j.envpol.2020.114428

184. Qi H, Fu D, Wang Z, Gao M, Peng L (2020) Microplastics occurrence and spatial distribution in seawater and sediment of Haikou Bay in the northern South China Sea. Estuar Coast Mar Sci. 239, 106757. https://doi.org/10.1016/j.ecss.2020.106757

185. Zhu X, Ran W, Teng J, Zhang C, Zhang W, Hou C, Zhao J, Qi X, Wang Q (2020) Microplastic Pollution in Nearshore Sediment from the Bohai Sea Coastline. Bull Environ Contam Toxicol. https://doi.org/10.1007/s00128-020-02866-1 
186. Li R, Yu L, Chai M, Wu H, Zhu X (2019) The distribution, characteristics and ecological risks of microplastics in the mangroves of Southern China. Sci Total Environ.135025. https://doi:10.1016/j.scitotenv.2019.135025

187. Zhang B, Wu D, Yang X, Teng J, Liu Y, Zhang C, Zhao J, Yin X, You L, Liu Y, Wang Q (2019) Microplastic pollution in the surface sediments collected from Sishili Bay, North Yellow Sea, China. Mar Pollut Bull. 141, 9-15. https://doi:10.1016/j.marpolbul.2019.02.021

188. Huang Y, Yan M, Xu K, Nie H, Gong H, Wang J (2019) Distribution characteristics of microplastics in Zhubi Reef from South China Sea. Environ Pollut. 113133. https://doi:10.1016/j.envpol.2019.113133

189. Zhang C, Zhou H, Cui Y, Wang C, Li Y, Zhang D (2018) Microplastics in offshore sediment in the Yellow Sea and East China Sea, China. Environ Pollut. 244:827-833. https://doi:10.1016/j.envpol.2018.10.102

190. Wang T, Zou X, Li B, Yao Y, Li J, Hui H, Yu W, Wang C (2018) Microplastics in a wind farm area: A case study at the Rudong Offshore Wind Farm, Yellow Sea, China. Mar Pollut Bull.128, 466-474. https://doi:10.1016/j.marpolbul.2018.01.050

191. Li J, Zhang H, Zhang K, Yang R, Li R, Li Y (2018) Characterization, source, and retention of microplastic in sandy beaches and mangrove wetlands of the Qinzhou Bay, China. Mar Pollut Bull.136, 401-406. https://doi.org/10.1016/j.marpolbul.2018.09.025

192. Li R, Zhang L, Xue B, Wang Y (2018) Abundance and characteristics of microplastics in the mangrove sediment of the semi-enclosed Maowei Sea of the South China Sea: New implications for location, rhizosphere, and sediment compositions. Environ Pollut. https://doi:10.1016/j.envpol.2018.10.089

193. Fok L, Cheung PK, Tang G, Li WC (2017) Size distribution of stranded small plastic debris on the coast of Guangdong, South China. Environ Pollut. 220, 407-412. https://doi:10.1016/j.envpol.2016.09.079

194. Peng G, Zhu B, Yang D, Su L, Shi H, Li D (2017) Microplastics in sediments of the Changjiang Estuary, China. Environ Pollut. 225, 283290. https://doi:10.1016/j.envpol.2016.12.064

195. Zhao S, Zhu L, Li D (2015) Microplastic in three urban estuaries, China. Environ Pollut. 206, 597-604. doi:10.1016/j.envpol.2015.08.027

196. Qiu Q, Peng J, Yu X, Chen F, Wang J, Dong F (2015) Occurrence of microplastics in the coastal marine environment: First observation on sediment of China. Mar Pollut Bull. 98(1-2), 274-280. https://doi.org/10.1016/j.marpolbul.2015.07.028

197. Zhou P, Huang C, Fang H, Cai W, Li D, Li X, Yu H (2011) The abundance, composition and sources of marine debris in coastal seawaters or beaches around the northern South China Sea (China). Mar Pollut Bull.62(9), 1998-

2007. https://doi.org/10.1016/j.marpolbul.2011.06.018

198. Herrera A, Raymond E, Martinez I, Alvarez S, Canning-Clode J, Gestoso I, Gomez M (2020) First evaluation of neustonic microplastics in the Macaronesian region, NE Atlantic. Mar Pollut Bull.153, 110999. https://doi.org/10.1016/j.marpolbul.2020.110999

199. Alvarez-Hernandez C, Cairos C, Lopez-Darias J, Mazzetti E, Hernandez-Sanchez C, Gonzalez-Salamo J, Hernandez-Borges J (2019) Microplastic debris in beaches of Tenerife (Canary Islands, Spain). Mar Pollut Bull.146, 26-32. https:// doi: 10.1016/j.marpolbul.2019.05.064

200. Edo C, Tamayo-Belda M, Martínez-Campos S, Martín-Betancor K, González-Pleiter M, Pulido-Reyes G, Rosal R (2019) Occurrence and identification of microplastics along a beach in the Biosphere Reserve of Lanzarote. Mar Pollut Bull.143, 220227. https://doi.org/10.1016/j.marpolbul.2019.04.061

201. Bayo J, Rojo D, Olmos S (2019) Abundance, morphology and chemical composition of microplastics in sand and sediments from a protected coastal area: The Mar Menor lagoon (SE Spain). Environ Pollut. 252, Pt-B, 1357-

1366, https://doi:10.1016/j.envpol.2019.06.024

202. Herrera A, Asensio M, Martinez I, Santana A, Packard T, Gomez M (2018) Microplastic and tar pollution on three Canary Islands beaches: An annual study. Mar Pollut Bull.129(2), 494-502. https://doi.org/10.1016/j.marpolbul.2017.10.020

203. Phuong NN, Poirier L, Lagarde F, Kamari A, Zalouk-Vergnoux A (2018) Microplastic abundance and characteristics in French Atlantic coastal sediments using a new extraction method. Environ Pollut. 243 (Pt A):228-237. https://doi: 10.1016/j.envpol.2018.08.032.

204. Kanhai LDK, Officer R, Lyashevska O, Thompson RC, O’Connor I (2017) Microplastic abundance, distribution and composition along a latitudinal gradient in the Atlantic Ocean. Mar Pollut Bull. 115 (1-2), 307-314. https://doi:10.1016/j.marpolbul.2016.12.025

205. Enders K, Lenz R, Stedmon CA, Nielsen TG (2015) Abundance, size and polymer composition of marine microplastics $\geq 10 \mu m$ in the Atlantic Ocean and their modelled vertical distribution. Mar Pollut Bull.100(1), 70-81. https://doi.org/10.1016/j.marpolbul.2015.09.027

206. Van Cauwenberghe L, Vanreusel A, Mees J, Janssen CR (2013) Microplastic pollution in deep-sea sediments. Environ Pollut. 182, 495499. https://doi:10.1016/j.envpol.2013.08.013

207. Ivar do Sul JA, Costa MF, Barletta M, Cysneiros FJA (2013) Pelagic microplastics around an archipelago of the Equatorial Atlantic. Mar Pollut Bull. 75 (1-2), 305-309. https://doi:10.1016/j.marpolbul.2013.07.040

208. Eriksen M, Maximenko N, Thiel M, Cummins A, Lattin G, Wilson S, Rifman S (2013) Plastic pollution in the South Pacific subtropical gyre. Mar Pollut Bull. 68(1-2), 71-76. https://doi.org/10.1016/j.marpolbul.2012.12.021

Page 22/30 
209. Dodsona GZ, Shotorban AK, Hatcher PG, Waggoner DC, Ghosal S, Noffk N (2020) Microplastic fragment and fiber contamination of beach sediments from selected sites in Virginia and North Carolina, USA. Mar Pollut Bull.151,

110869. https://doi.org/10.1016/j.marpolbul.2019.110869

210. Leads RR, Weinstein JE (2019) Occurrence of tire wear particles and other microplastics within the tributaries of the Charleston Harbor Estuary, South Carolina, USA. Mar Pollut Bull.145, 569-582.

https://doi.org/10.1016/j.marpolbul.2019.06.061

211. Ramirez-Alvarez N, Mendoza LMR, Vinicio Macias-Zamora J, Oregel-Vázquez L, Alvarez-Aguilar A, Hernandez-Guzman FA, SanchezOsorio JL, Moore CJ, Silva-Jimenez H, Navarro-Olache LF, Navarro-Olache LF (2019) Microplastics: Sources and Distribution in Surface Waters and Sediments of Todos Santos Bay, Mexico. Sci Total Environ.134838. https://doi:10.1016/j.scitotenv.2019.134838

212. McEachern K, Alegria H, Kalagher AL, Hansen C, Morrison S, Hastings D (2019) Microplastics in Tampa Bay, Florida: Abundance and variability in estuarine waters and sediments. Mar Pollut Bull.148, 97-106. https://doi:10.1016/j.marpolbul.2019.07.068

213. Pinon-Colin T. de J, Rodriguez-Jimenez R, Pastrana-Corral MA, Rogel-Hernandez E, Wakida FT (2018) Microplastics on sandy beaches of the Baja California Peninsula, Mexico. Mar Pollut Bull.131, 63-71. https://doi:10.1016/j.marpolbul.2018.03.055

214. Gray AD, Wertz H, Leads RR, Weinstein JE (2018) Microplastic in two South Carolina Estuaries: Occurrence, distribution, and composition. Mar Pollut Bull.128, 223-233. https://doi.org/10.1016/j.marpolbul.2018.01.030

215. Sutton R, Mason SA, Stanek SK, Willis-Norton E, Wren IF, Box C (2016) Microplastic contamination in the San Francisco Bay, California, USA. Mar Pollut Bull.109 (1), 230-235. https://doi: 10.1016/j.marpolbul.2016.05.077

216. Retama I, Jonathan MP, Shruti VC, Velumani S, Sarkar SK, Roy PD, Rodriguez-Espinosa PF (2016) Microplastics in tourist beaches of Huatulco Bay, Pacific coast of southern Mexico. Mar Pollut Bull.113(1-2), 530-535.https://doi:10.1016/j.marpolbul.2016.08.053

217. Wessel CC, Lockridge GR, Battiste D, Cebrian J (2016) Abundance and characteristics of microplastics in beach sediments: Insights into microplastic accumulation in northern Gulf of Mexico estuaries. Mar Pollut Bull. 109(1), 178183. https://doi.org/10.1016/j.marpolbul.2016.06.002

218. Ballent A, Corcoran PL, Madden O, Helm PA, Longstaffe FJ (2016) Sources and sinks of microplastics in Canadian Lake Ontario nearshore, tributary and beach sediments. Mar Pollut Bull. 110 (1), 383-395. https://doi.org/10.1016/j.marpolbul.2016.06.037

219. Yonkos LT, Friedel EA, Perez-Reyes AC, Ghosal S, Arthur CD (2014) Microplastics in Four Estuarine Rivers in the Chesapeake Bay, U.S.A. Environ Sci Technol. 48(24), 14195-14202. https://doi:10.1021/es5036317

220. Tata T, Belabed BE, Bououdina M, Bellucci S (2020) Occurrence and characterization of surface sediment microplastics and litter from North African coasts of Mediterranean Sea: Preliminary research and first evidence. Sci Total

Environ.136664. https://doi:10.1016/j.scitotenv.2020.136664

221. Filgueiras AV, Gago J, Campillo JA, Leon VM (2019) Microplastic distribution in surface sediments along the Spanish Mediterranean continental shelf. Environ Sci Pollut Res. https://doi:10.1007/s11356-019-05341-5

222. Yabanli M, Yozukmaz A, Sener I, Olmez OT (2019) Microplastic pollution at the intersection of the Aegean and Mediterranean Seas: A study of the Datca Peninsula (Turkey). Mar Pollut Bull.145, 47-55. https://doi.org/10.1016/j.marpolbul.2019.05.003

223. Constant M, Kerherve P, Mino-Vercellio-Verollet M, Dumontier M, Sanchez Vidal A, Canals M, Heussner S (2019) Beached microplastics in the Northwestern Mediterranean Sea. Mar Pollut Bull.142, 263-273. https://doi.org/10.1016/j.marpolbul.2019.03.032

224. Karkanorachaki K, Kiparissis S, Kalogerakis GC, Yiantzi E, Psillakis E, Kalogerakis N (2018) Plastic pellets, meso- and microplastics on the coastline of Northern Crete: Distribution and organic pollution. Mar Pollut Bull.133, 578589. https://doi.org/10.1016/j.marpolbul.2018.06.011

225. Abidli S, Antunes JC, Ferreira JL, Lahbib Y, Sobral P, Trigui El Menif N (2018) Microplastics in sediments from the littoral zone of the north Tunisian coast (Mediterranean Sea). Estuar Coast Mar Sci. 205, 1-9. https://doi.org/10.1016/j.ecss.2018.03.006

226. Alomar C, Estarellas F, Deudero S (2016) Microplastics in the Mediterranean Sea: Deposition in coastal shallow sediments, spatial variation and preferential grain size. Mar Environ Res. 115, 1-10. https:// doi: 10.1016/j.marenvres.2016.01.005

227. Ioakeimidis C, Zeri C, Kaberi H, Galatchi M, Antoniadis K, Streftaris N, Papatheodorou G (2014) A comparative study of marine litter on the seafloor of coastal areas in the Eastern Mediterranean and Black Seas. Mar Pollut Bull. 89(1-2), 296304. https://doi.org/10.1016/j.marpolbul.2014.09.044

228. Ashton K, Holmes L, Turner A (2010) Association of metals with plastic production pellets in the marine environment. Mar Pollut Bull. 60 (11), 2050-2055. https://doi.org/10.1016/j.marpolbul.2010.07.014

229. Urban-Malinga B, Zalewski M, Jakubowska A, Wodzinowski T, Malinga M, Pałys B, Dąbrowska A (2020) Microplastics on sandy beaches of the southern Baltic Sea. Mar Pollut Bull.155, 111170. https://doi:10.1016/j.marpolbul.2020.111170

Page 23/30 
230. Hengstmann E, Tamminga M, vom Bruch, Fischer EK (2018) Microplastic in beach sediments of the Isle of Rügen (Baltic Sea) Implementing a novel glass elutriation column. Mar Pollut Bull. 126, 263-274.

231. Esiukova E (2017) Plastic pollution on the Baltic beaches of Kaliningrad region, Russia. Mar Pollut Bull. 114(2), 10721080. https://doi.org/10.1016/j.marpolbul.2016.10.001

232. Graca B, Szewc K, Zakrzewska D, Dołęga A, Szczerbowska-Boruchowska M (2017) Sources and fate of microplastics in marine and beach sediments of the Southern Baltic Sea-a preliminary study. Environ Sci Pollut Res. 24(8), 7650-7661. https://doi:10.1007/s11356017-8419-5

233. Zobkov M, Esiukova E (2016) Microplastics in Baltic bottom sediments: Quantification procedures and first results. Mar Pollut Bull. 114 (2), 724-732. https://doi:10.1016/j.marpolbul.2016.10.060

234. Tamminga M, Hengstmann E, Fischer EK (2018) Microplastic analysis in the South Funen Archipelago, Baltic Sea, implementing manta trawling and bulk sampling. Mar Pollut Bull.128, 601-608. https://doi.org/10.1016/j.marpolbul.2018.01.066

235. Stolte A, Forster S, Gerdts G, Schubert H (2015) Microplastic concentrations in beach sediments along the German Baltic coast. Mar Pollut Bull.99 (1-2), 216-229. https://doi.org/10.1016/j.marpolbul.2015.07.022

236. Wang S, Chen H, Zhou X, Tian Y, Lin C, Wang W, Zhou K, Zhang Y, Lin H (2020) Microplastic abundance, distribution and composition in the mid-west Pacific Ocean. Environ Pollut. 114125. https://doi:10.1016/j.envpol.2020.114125

237. Zhang D, Liu X, Huang W, Li J, Wang C, Zhang D, Zhang C (2020) Microplastic pollution in deep-sea sediments and organisms of the Western Pacific Ocean. Environ Pollut. 113948. https://doi:10.1016/j.envpol.2020.113948

238. Ryan PG, Schofield A. (2020). Low densities of macroplastic debris in the Pitcairn Islands Marine Reserve. Mar Pollut Bull.157, 111373. https://doi:10.1016/j.marpolbul.2020.111373

239. Pan Z, Liu Q, Sun Y, Sun X, Lin H (2019) Environmental implications of microplastic pollution in the Northwestern Pacific Ocean. Mar Pollut Bull. 146, 215-224. https://doi.org/10.1016/j.marpolbul.2019.06.031

240. Lebreton L, Slat B, Ferrari F, Sainte-Rose B, Aitken J, Marthouse R, Reisser J (2018) Evidence that the Great Pacific Garbage Patch is rapidly accumulating plastic. Sci Rep. 8(1). https://doi:10.1038/s41598-018-22939-w

241. Geyer R, Jambeck JR, Law KL (2017) Production, use, and fate of all plastics ever made. Sci Adv. 3(7), 1-5. https://doi:10.1126/sciadv.1700782

242. Eriksen M, Lebreton LCM, Carson HS, Thiel M, Moore CJ, Borerro JC, Reisser J (2014) Plastic Pollution in the World's Oceans: More than 5 Trillion Plastic Pieces Weighing over 250,000 Tons Afloat at Sea. PLoS ONE, 9(12),

e111913. https://doi.org/10.1371/journal.pone.0111913

243. Eriksen M, Maximenko N, Thiel M, Cummins A, Lattin G, Wilson S, Rifman S (2013) Plastic pollution in the South Pacific subtropical gyre. Mar Pollut Bull. 68(1-2), 71-76. https://doi.org/10.1016/j.marpolbul.2012.12.021

244. Watters DL, Yoklavich MM, Love MS, Schroeder DM (2010) Assessing marine debris in deep seafloor habitats off California. Mar Pollut Bull. 60 (1), 131-138. https://doi:10.1016/j.marpolbul.2009.08.019

245. Karlsson TM, Vethaak AD, Almroth BC, Ariese F, Van Velzen M, Hassellöv M, Leslie HA (2017) Screening for microplastics in sediment, water, marine invertebrates and fish: Method development and microplastic accumulation. Mar Pollut Bull. 122(1-2), 403-408. https://doi:10.1016/j.marpolbul.2017.06.081

246. Kazour M, Jemaa S, Issa C, Khalaf G, Amara R (2019) Microplastics pollution along the Lebanese coast (Eastern Mediterranean Basin): Occurrence in surface water, sediments and biota samples. Sci. Total Environ.133933. https://doi:10.1016/j.scitotenv.2019.133933

247. Van Cauwenberghe L, Vanreusel A, Mees J, Janssen CR (2013) Microplastic pollution in deep-sea sediments. Environ Pollut. 182, 495499. https://doi:10.1016/j.envpol.2013.08.013

\section{Tables}

Table 1 shows the concentration, size, and distribution of microplastics in marine and biota environments 


\begin{tabular}{|c|c|c|c|c|c|c|c|c|}
\hline $\begin{array}{l}\text { S. } \\
\text { No }\end{array}$ & $\begin{array}{c}\text { Location/ } \\
\text { Environments }\end{array}$ & Sample type & $\begin{array}{l}\text { MPs Range/ } \\
\text { average }\end{array}$ & Size & $\begin{array}{c}\text { Distribution } \\
(\%)\end{array}$ & Ingestion & Spectroscopy & Polymer types \\
\hline & $\begin{array}{l}\text { Kochi, Arabian Sea, } \\
\text { India [56] }\end{array}$ & Fishes -24 & - & $\begin{array}{l}>1-5 \\
\mathrm{~mm}\end{array}$ & 81.59 & $\begin{array}{l}\text { Gut, } \\
\text { intestine }\end{array}$ & $\begin{array}{l}\text { Raman } \\
\text { spectroscopy } \\
\text { \& FTIR }\end{array}$ & PE; PP; LDPE \\
\hline & $\begin{array}{ll}\text { Cochin, } & \text { Kerala, } \\
\text { India [57] } & \end{array}$ & $\begin{array}{l}\text { Fenneropenaeus } \\
\text { indices } \\
(\text { Shrimp - 330) }\end{array}$ & $\begin{array}{l}0.39 \pm 0.6 \\
\text { items/shrimp } \\
0.04 \pm 0.07 \\
\text { items/g }\end{array}$ & $\begin{array}{l}500- \\
1000 \\
\mu \mathrm{m}\end{array}$ & 30.9 & $\begin{array}{l}\text { Foregut and } \\
\text { Midgut }\end{array}$ & FTIR & PA; PEST; PE; PP \\
\hline & \multirow[t]{2}{*}{$\begin{array}{l}\text { Pondicherry, India } \\
{[58]}\end{array}$} & \multirow{2}{*}{$\begin{array}{l}\text { Perna viridis \& } \\
\text { Meretrix } \\
\text { meretrix } \\
\text { (bivalve -50) }\end{array}$} & $1.8 \mathrm{~g}$ & \multirow[t]{2}{*}{$\begin{array}{l}<100 \\
\mu \mathrm{m}\end{array}$} & \multirow[t]{2}{*}{-} & \multirow[t]{2}{*}{$\begin{array}{l}\text { Mussels / } \\
\text { clams }\end{array}$} & \multirow{2}{*}{$\begin{array}{l}\text { Raman } \\
\text { spectrum \& } \\
\text { Fluorescence } \\
\text { microscope }\end{array}$} & \multirow{2}{*}{$\begin{array}{ll}\text { PU;PVCA; PVC; } & \text { PES; } \\
\text { PVCA; PET; } & \text { ABS; } \\
\text { SBR; PVK; PET; PVC; } & \text { PEVA }\end{array}$} \\
\hline & & & $0.18 \mathrm{~g}$ & & & & & \\
\hline & \multirow{3}{*}{$\begin{array}{l}\begin{array}{l}\text { Tuticorin, Gulf of } \\
\text { Mannar } \\
\text { (GoM), } \\
\text { India [59] }\end{array} \\
\end{array}$} & $\begin{array}{l}\text { Donax } \\
\text { cuneatus (225) }\end{array}$ & 0.95 items $/ g$ & $\begin{array}{l}100- \\
250 \mu \mathrm{m}\end{array}$ & 41 & Clam & \multirow{3}{*}{$\begin{array}{l}\text { FTIR-ATR, } \\
\text { SEM, \& } \\
\text { EDAX }\end{array}$} & \multirow{3}{*}{$\begin{array}{l}\text { PE; PP; PP-PE; } \\
\text { PA;PET; PEST; PVC; } \\
\text { PS; RA; PVA }\end{array}$} \\
\hline & & Sediments & $\begin{array}{l}134.29 \\
\text { items/kg }\end{array}$ & $\begin{array}{ll}1-5 \\
\mathrm{~mm}\end{array}$ & 44 & - & & \\
\hline & & Sea water & 19.87 items / & $\begin{array}{l}500 \mu \mathrm{m} \\
-1 \mathrm{~mm}\end{array}$ & 58 & - & & \\
\hline & \multirow[t]{2}{*}{$\begin{array}{l}\text { Tuticorin, } \\
\text { Southeast coast of } \\
\text { India [60] }\end{array}$} & $\begin{array}{l}\text { Harpodon } \\
\text { nehereus (20), } \\
\text { Chirocentrus } \\
\text { dorab (20), } \\
\text { Sardinella } \\
\text { albella (20), } \\
\text { Rastrelliger } \\
\text { kanagurta (20), } \\
\text { Katsuwonus } \\
\text { pelamis (10), \& } \\
\text { Istiophorus } \\
\text { platypterus (10) }\end{array}$ & $\begin{array}{l}0.2002 \\
\text { items/l }\end{array}$ & $\begin{array}{l}<500 \\
\mu \mathrm{m}\end{array}$ & 34 & $\begin{array}{l}\text { Gastrointestinal } \\
\text { tracts }\end{array}$ & \multirow[t]{2}{*}{$\begin{array}{l}\text { FTIR-ATR } \\
\text { and SEM- } \\
\text { EDAX }\end{array}$} & $\begin{array}{l}\text { PE; PA; PEST; PS; } \\
\text { PP; PAC }\end{array}$ \\
\hline & & Sea water & 13.4 items $/ 1$ & $\begin{array}{l}1-5 \\
m m\end{array}$ & 64 & - & & $\begin{array}{l}\text { PE; PEST; PA; PS; PP; } \\
\text { PD; PP-PE; PVA }\end{array}$ \\
\hline & \multirow[t]{2}{*}{ Kerala, India [57] } & \multirow{2}{*}{$\begin{array}{l}\text { Rastrelliger } \\
\text { kanagurta, } \\
\text { Megalaspis } \\
\text { cordyla, } \\
\text { Sardinella } \\
\text { longiceps, } \\
\text { Sardinella } \\
\text { gibbosa, } \\
\text { Stolephorus } \\
\text { indicus, } \\
\text { Dussumieria } \\
\text { acuta, Thryssa } \\
\text { dussumieri, } \\
\text { Sphyraena and } \\
\text { obtusata Anodontostoma } \\
\text { chacunda }\end{array}$} & 0.005 items $/ g$ & $\begin{array}{l}115- \\
210 \\
\mu \mathrm{m}\end{array}$ & 41.1 & Edible Tissues & \multirow[t]{2}{*}{ ATR- FTIR } & $\mathrm{PE} ; \mathrm{PP}$ \\
\hline & & & 0.054 items /g & $\begin{array}{l}136 \text { to } \\
4010 \\
\mu \mathrm{m}\end{array}$ & 7 & Inedible tissues & & $\begin{array}{l}\text { PE; PP; } \\
\text { EPDM; PS }\end{array}$ \\
\hline & $\begin{array}{l}\text { Ramsar, Vembanad } \\
\text { Lake, South India } \\
{[61]}\end{array}$ & $\begin{array}{l}\text { Piaractus } \\
\text { brachypomus }\end{array}$ & 26.01 items/g & $0.5 \mathrm{~mm}$ & 99 & Gut & $\begin{array}{l}\text { ATR-FTIR \& } \\
\text { Raman } \\
\text { Spectroscopy }\end{array}$ & PP; NY6; PET; PBT \\
\hline & $\begin{array}{l}\text { Chennai and } \\
\text { Nagapattinam, } \\
\text { Southeast coast of } \\
\text { the Bay of Bengal } \\
{[62]}\end{array}$ & Fish (190) & 20 items/g & $\begin{array}{l}1.3 \mu \mathrm{m}- \\
9.3 \mathrm{~mm}\end{array}$ & 8.95 & $\begin{array}{l}\text { Gastrointestinal } \\
\text { tract }\end{array}$ & FTIR \& SEM & PA; PE; PET \\
\hline & $\begin{array}{l}\text { Chennai, Southeast } \\
\text { coast of India [63] }\end{array}$ & $\begin{array}{l}\text { Perna viridis } \\
\text { (Linnaeus, 1758) }\end{array}$ & $0.9 / 9$ & $\begin{array}{l}5-30 \\
\mu \mathrm{m} \\
\end{array}$ & 87 & Tissue & $\begin{array}{l}\text { DXR Raman } \\
\text { spectroscopic }\end{array}$ & PS \\
\hline \multirow{4}{*}{ 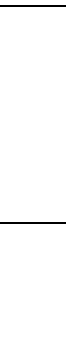 } & \multirow{3}{*}{$\begin{array}{l}\text { Roche } \\
\text { Tuticorin } \text { coark, } \\
\text { Gulf of Mannar, } \\
\text { Southeastern India } \\
{[64]}\end{array}$} & $\begin{array}{l}\text { Magallana } \\
\text { bilineata (oyster) }\end{array}$ & $0.81 / g$ & $\begin{array}{l}0.25 \text { to } \\
0.5 \mathrm{~mm}\end{array}$ & 96 & Tissue & \multirow[t]{3}{*}{$\begin{array}{l}\text { FTIR-ATR } \\
\text { analysis }\end{array}$} & PE; PP \\
\hline & & Sediments & $\begin{array}{l}12.75 \\
\text { items/kg }\end{array}$ & $\begin{array}{l}1-3 \\
\mathrm{~mm}\end{array}$ & 100 & - & & PE; PP; PEST; PA \\
\hline & & Seawater & 21.60 items/L & $\begin{array}{l}0.5-1 \\
\mathrm{~mm}\end{array}$ & 100 & - & & PE; PP \\
\hline & $\begin{array}{l}\text { Tuticorin, South } \\
\text { east coast of India } \\
{[65]}\end{array}$ & $\begin{array}{l}\text { Rastrilleger } \\
\text { kanagurta and } \\
\text { Epinephalus } \\
\text { merra } \\
\end{array}$ & - & $\begin{array}{l}0.5 \mathrm{~mm} \\
\text { to } 1 \\
\mathrm{~mm}\end{array}$ & 80 & gut & FTIR & PE; PP \\
\hline
\end{tabular}

Page 25/30 


\begin{tabular}{|c|c|c|c|c|c|c|c|}
\hline & $\begin{array}{l}\text { Kochi, } \\
\text { Southeastern } \\
\text { Arabian Sea [66] }\end{array}$ & $\begin{array}{l}\text { Sternaspis } \\
\text { scutata, } \\
\text { Magelona cinta } \\
\text { and Tellina sp }\end{array}$ & - & $20 \mu \mathrm{m}$ & 67 & $\begin{array}{l}\text { DXR Raman } \\
\text { microscope }\end{array}$ & PS \\
\hline \multicolumn{8}{|c|}{ Beach } \\
\hline \multirow[t]{2}{*}{$\begin{array}{l}\text { S. } \\
\text { No }\end{array}$} & $\begin{array}{c}\text { Location/ } \\
\text { Environments }\end{array}$ & Sample type & $\begin{array}{c}\text { MPs Range/ } \\
\text { average }\end{array}$ & Size & $\begin{array}{c}\text { Distribution } \\
(\%)\end{array}$ & spectroscopy & Polymer types \\
\hline & $\begin{array}{lr}\text { Silver } & \text { Beach, } \\
\text { Southern India [69] }\end{array}$ & Plastic debris & 204 items $/ \mathrm{kg}$ & $\begin{array}{l}0.5 \text { to } \\
1 \mathrm{~mm}\end{array}$ & 100 & ATR-FTIR & PVC; PE; NY \\
\hline & \multirow{3}{*}{$\begin{array}{lr}\text { Beaches } & \text { of } \\
\text { Tuticorin } & \text { Southern } \\
\text { India [70] }\end{array}$} & Macroplastics & 3.77 items $/ \mathrm{m}^{2}$ & $\begin{array}{l}>\quad 2.5 \\
\mathrm{~cm}\end{array}$ & 54.98 & \multirow[t]{3}{*}{ ATR-FTIR } & \multirow[t]{3}{*}{$\begin{array}{l}\text { PE; PP; PET; NY; PS, } \\
\text { PVC }\end{array}$} \\
\hline & & Mesoplastics & 9.5 items $/ \mathrm{m}^{2}$ & $\begin{array}{l}5 \mathrm{~mm}- \\
2.5 \mathrm{~cm}\end{array}$ & 60 & & \\
\hline & & $\begin{array}{l}\text { Microplastic } \\
\text { debris }\end{array}$ & 54 items $/ \mathrm{m}^{2}$ & $5 \mathrm{~mm}$ & 41.17 & & \\
\hline & $\begin{array}{lr}\text { Tuticorin } & \text { and } \\
\text { Vembar groups of } \\
\text { islands in the Gulf } \\
\text { of } \\
\text { southeast } \\
{[71]}\end{array}$ & $\begin{array}{l}\text { reported that the } \\
\text { MPs ranged from } \\
60 \text { to } 126.6 \\
\text { items/L in water } \\
\text { and from } 50 \text { to } \\
103.8 \text { items } / \mathrm{kg} \text { in } \\
\text { sediment, PE } \\
\text { fibers (1-3 } \mathrm{mm}) \\
\text { and PP } \\
\text { fragments (3- } \\
5 \mathrm{~mm}) \text { were the } \\
\text { most common } \\
\text { forms of } \\
\text { microplastics }\end{array}$ & & & & & \\
\hline & $\begin{array}{l}\text { Marina Beach in } \\
\text { Chennai, India [72] }\end{array}$ & Plastics debris & 2275 items & $\begin{array}{l}5.5 \text { to } \\
25 \mathrm{~mm}\end{array}$ & 100 & ATR-FTIR; TGA-DSC; SEM & LDPE; PE; PP; PA; PC \\
\hline & $\begin{array}{lr}\text { South } & \text { Andaman } \\
\text { beaches, India [73] }\end{array}$ & Sediments & $\begin{array}{l}414.35 \\
\text { items/Kg }\end{array}$ & $\begin{array}{l}100- \\
1000 \\
\mu \mathrm{m}\end{array}$ & 100 & Raman spectral & $\begin{array}{l}\text { PP; PPM, PVF, PBAN; } \\
\text { PSF; PPO; PVB; PVC; } \\
\text { NY; ABS }\end{array}$ \\
\hline & $\begin{array}{l}\text { North-east Arabian } \\
\text { coast, } \\
\text { India [74] }\end{array}$ & Marine debris & $\begin{array}{l}22.4 \mathrm{~kg} \mathrm{dry} \\
\text { weight } / \mathrm{km}^{2}\end{array}$ & - & 40.6 & - & $\begin{array}{l}\text { Plastic bags, Food } \\
\text { wrappers, Personal } \\
\text { care products, Cups } \\
\text { (Styrofoam), } \\
\text { Beverage bottles, } \\
\text { Plastic rope/ net } \\
\text { pieces, Bottle or } \\
\text { container caps }\end{array}$ \\
\hline & $\begin{array}{l}\text { Beach sediments of } \\
\text { coastal areas in } \\
\text { Tamil Nadu India } \\
{[77]}\end{array}$ & Sediment & 385 items $/ \mathrm{kg}$ & $\begin{array}{l}0.5 \text { to } \\
3 \mathrm{~mm}\end{array}$ & 100 & FTIR-ATR SEM-EDAX & PE; PP; NY; PES; PS \\
\hline & $\begin{array}{l}\text { Arabian sea coast, } \\
\text { Bay of Bengal } \\
\text { coast, India [78] }\end{array}$ & Beach sand & $220 \mathrm{MPs} / \mathrm{kg}$ & $\begin{array}{ll}> & 1 \\
\mathrm{~mm} & \end{array}$ & 100 & $\begin{array}{l}\text { Fluorescence microscopy, SEM- } \\
\text { EDS, and FTIR }\end{array}$ & $\begin{array}{l}\text { PET; PE; PVC; PP; PS; } \\
\text { PEST; PA }\end{array}$ \\
\hline & & Beach sand & $181 \mathrm{MPs} / \mathrm{kg}$ & & & & \\
\hline & & Beach sand & $45 \mathrm{MPs} / \mathrm{kg}$ & & & & \\
\hline & $\begin{array}{l}\text { Beaches in Kerala } \\
\text { Coast, India [79] }\end{array}$ & Plastics & $\begin{array}{l}0.55 \\
\mathrm{~kg} / 100 \mathrm{~m}^{2}\end{array}$ & - & 73.8 & - & Plastic \\
\hline & $\begin{array}{l}\text { Nattika Beach, } \\
\text { Kerala Coast, India } \\
{[80]}\end{array}$ & Sediments & 191 items $/ \mathrm{kg}$ & $5-1 \mathrm{~mm}$ & 70 & FTIR and SEM & $\begin{array}{l}\text { PE; PE + PP; PP; PS; } \\
\text { PCU }\end{array}$ \\
\hline & $\begin{array}{l}\text { Chennai, East } \\
\text { Coast of India [81] }\end{array}$ & Plastic debris & $8.96 \mathrm{~kg} / \mathrm{m}$ & - & 56.42 & - & $\begin{array}{l}\text { Food wrappers; cups; } \\
\text { bottle and caps; } \\
\text { thermocol/styrofoam; } \\
\text { food wrappers }\end{array}$ \\
\hline & Beaches of & Beach sediments & $72.03 \pm 19.16$ & 300 & 56.32 & Raman spectroscopy & PP; HDPE; LDPE; PS; \\
\hline
\end{tabular}




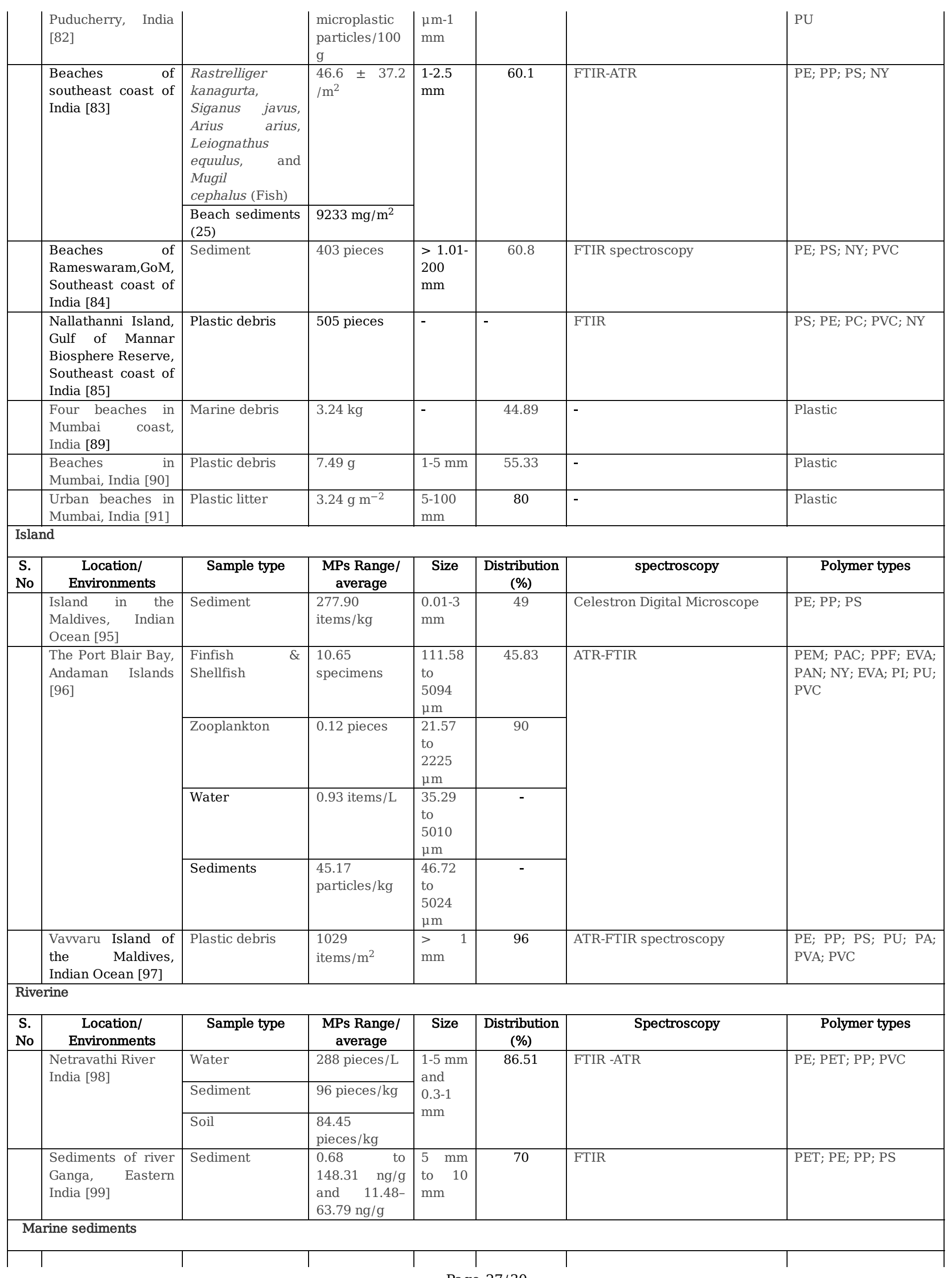




\begin{tabular}{|c|c|c|c|c|c|c|c|}
\hline \begin{tabular}{l|} 
S. \\
No
\end{tabular} & $\begin{array}{c}\text { Location/ } \\
\text { Environments }\end{array}$ & Sample type & $\begin{array}{l}\text { MPs Range/ } \\
\text { average }\end{array}$ & Size & $\begin{array}{c}\text { Distribution } \\
(\%)\end{array}$ & Spectroscopy & Polymer types \\
\hline & \multirow[t]{3}{*}{$\begin{array}{l}\text { Kerala, Southwest } \\
\text { coast of India [76] }\end{array}$} & Sediments & $\begin{array}{l}40.7 \\
\text { particles } / \mathrm{m}^{2}\end{array}$ & \multirow{3}{*}{$\begin{array}{lr}0.3 \quad- \\
0.6 ; 0.6 \\
-1.18 \text {; } \\
1.18 \quad- \\
2.36 \\
\text { and } \\
2.36 \quad- \\
4.75 \\
\mathrm{~mm}\end{array}$} & \multirow[t]{3}{*}{96.10} & \multirow[t]{3}{*}{ FTIR-ATR; FP-XRF } & $\begin{array}{l}\text { PE; PP; PA; PS; PET; } \\
\text { RY; } \\
\text { PUR; CE; ABS; PVC; } \\
\text { PVFM }\end{array}$ \\
\hline & & Water & $\begin{array}{l}1.25 \\
\text { particles/L }\end{array}$ & & & & PE; PP; RY; PS; CE \\
\hline & & Fish & 22 particles & & & & PE; CE; RY; PL; PP \\
\hline & $\begin{array}{l}\text { Vembanad Lake, } \\
\text { Kerala, India [86] }\end{array}$ & Sediments & $496{\text { items } \mathrm{m}^{-2}}^{2}$ & $\begin{array}{ll}< & 5 \\
\mathrm{~mm} & \end{array}$ & 91 & Raman spectra & PP; PE; PS \\
\hline & $\begin{array}{lll}\text { Goa } & \text { coast, India } \\
{[88]} & & \end{array}$ & Sediments & 3000 pellets & - & - & FTIR-ATR & PE; PP \\
\hline & $\begin{array}{ll}\text { Chennai } & \text { coast, } \\
\text { India [150] } & \\
\end{array}$ & MPPs & 1200 pellets & $\begin{array}{l}2 \text { to } 5 \\
\mathrm{~mm}\end{array}$ & - & ATR-FTIR & PE; PP \\
\hline \multicolumn{8}{|c|}{ Sea salt } \\
\hline $\begin{array}{l}\text { S. } \\
\text { No }\end{array}$ & $\begin{array}{c}\text { Location/ } \\
\text { Environments }\end{array}$ & Sample type & $\begin{array}{l}\text { MPs Range/ } \\
\text { average }\end{array}$ & Size & $\begin{array}{c}\text { Distribution } \\
(\%)\end{array}$ & Spectroscopy & Polymer types \\
\hline & $\begin{array}{l}\text { Tuticorin Coastal } \\
\text { salt pan stations, } \\
\text { Gulf of Mannar, } \\
\text { South India [92] }\end{array}$ & Sea salt & - & $\begin{array}{l}100 \\
\mu \mathrm{m}\end{array}$ & 60 & $\mu$-FT-IR and AFM & PE; PP; CL; NY \\
\hline & $\begin{array}{l}\text { Salt of Tuticorin, } \\
\text { Southeast Coast of } \\
\text { India [93] }\end{array}$ & Sea salt & 72 items $/ \mathrm{kg}$ & $\begin{array}{l}100 \text { to } \\
500 \mu \mathrm{m}\end{array}$ & 100 & SEM-EDAX & PE; PP; PEST; PA \\
\hline & $\begin{array}{l}\text { Mumbai, Indian sea } \\
\text { salts [94] }\end{array}$ & Sea salt & $\begin{array}{l}103 \text { particles } \\
\mathrm{kg}^{-1}\end{array}$ & $\begin{array}{l}2000 \\
\mu \mathrm{m} \\
\text { and } \\
500 \\
\mu \mathrm{m}\end{array}$ & 80 & $\mu$-FTIR & PP; PS; PA; PE \\
\hline \multicolumn{8}{|c|}{ Lake (water \& sediments) } \\
\hline & \multirow{2}{*}{$\begin{array}{ll}\text { Veeranam } & \text { lake, } \\
\text { Tamil Nadu, } & \text { India } \\
{[100]} & \\
\end{array}$} & Sediments & 309 items $/ \mathrm{kg}$ & $\begin{array}{l}-1 \quad \text { to } \\
0.3 \mathrm{~mm}\end{array}$ & \multirow[t]{2}{*}{80} & \multirow[t]{2}{*}{ ATR-FTIR } & \multirow[t]{2}{*}{ NY; PE; PS; PP; PVC } \\
\hline & & Water & 28 items/L & $\begin{array}{l}0.3-2 \\
\mathrm{~mm}\end{array}$ & & & \\
\hline & \multirow[t]{2}{*}{$\begin{array}{lrl}\text { Red Hills } & \text { Lake, } \\
\text { India } & {[101]} & \end{array}$} & Water & 5.9 items/L & $\begin{array}{l}0.33-2 \\
\mathrm{~mm}\end{array}$ & \multirow[t]{2}{*}{99} & \multirow[t]{2}{*}{ ATR-FTIR, SEM } & \multirow[t]{2}{*}{$\begin{array}{l}\text { HDPE; } \\
\text { LDPE; PP; PS }\end{array}$} \\
\hline & & Sediments & 27 items//kg & $2 \mathrm{~mm}$ & & & \\
\hline \multicolumn{8}{|c|}{ Seawater } \\
\hline & $\begin{array}{l}\text { South Juhu creek, } \\
\text { Mumbai, India [68] }\end{array}$ & Marine debris & $2 \mathrm{~g} / \mathrm{kg}$ & Macro & - & - & - \\
\hline
\end{tabular}

\begin{abstract}
Abbreviations
ABS Acrylonitrile Butadiene Styrene; ATR-FTIR Attenuated Total Reflectance - Fourier Transform Infrared Spectrometry; CL Cellulose; CP Cellophane; EVA Ethylene-Vinyl Acetate; EVOH Ethylene vinyl alcohol; EVOH Ethylene Vinylalcohol; FTIR Fourier Transform Infrared Spectrometry; GC-ITMS Gas chromatography - Ion trap mass spectrometry; HDPE High-Density Polyethylene; LDPE Low-Density Polyethylene; MMA Polymethyl Methacrylate; NY Nylon; PA Polyamide; PAC Polyacrylic; PAHs Polycyclic Aromatic Hydrocarbons; PAN Polyacrylonitrile; PBAN Polybutadiene acrylonitrile acrylic acid; PBR polybutadiene; PC Polycarbonate; PCU Polycarbonate-Urethane; PD Polydiene; PDMS Polymethylsiloxane; PE Polyethylene; PEA Polyethylene Glycol Adipate; PEI Polyetherimide; PEST Polyester; PET Polyethylene Terephthalate; PEVA Polyethylene-Vinyl Acetate; PI Polyisoprene; PMM Polymelamine; PP Polypropylene; PPA Polyphthalamide; PPF Polyphenylene sulfide; PPO Poly perfluoroethylene oxide; PPS Polyphenylene sulfide; PS Polystyrene; PSF Polysulfide; PSS Polystyrene sulfonate; PTFE Polytetrafluoroethylenes; PU Polyurethane; PVA Polyvinyl Acetate; PVAc Polyvinyl Alcohol; PVAC polyvinyl/vinyl Acetate Copolymer; PVB Polyvinyl Benzoate; PVBP Poly (4-vinylbiphenyl); PVC Polyvinyl Chloride; PVCAP Poly 4methylcaprolactam; PVCE Polyvinyl Chloride-Ethylene; PVE Polyvinyl Ester; PVF Polyvinyl formal; RPP Resin Polypropylene; RY Rayon; SEM Scanning Electron Microscopy; SEM-EDS Scanning Electron Microscopy - Energy Dispersive Spectroscopy; TGA-DSC Thermogravimetric Analysis \& Differential Scanning Calorimetry.
\end{abstract}

\title{
Figures
}




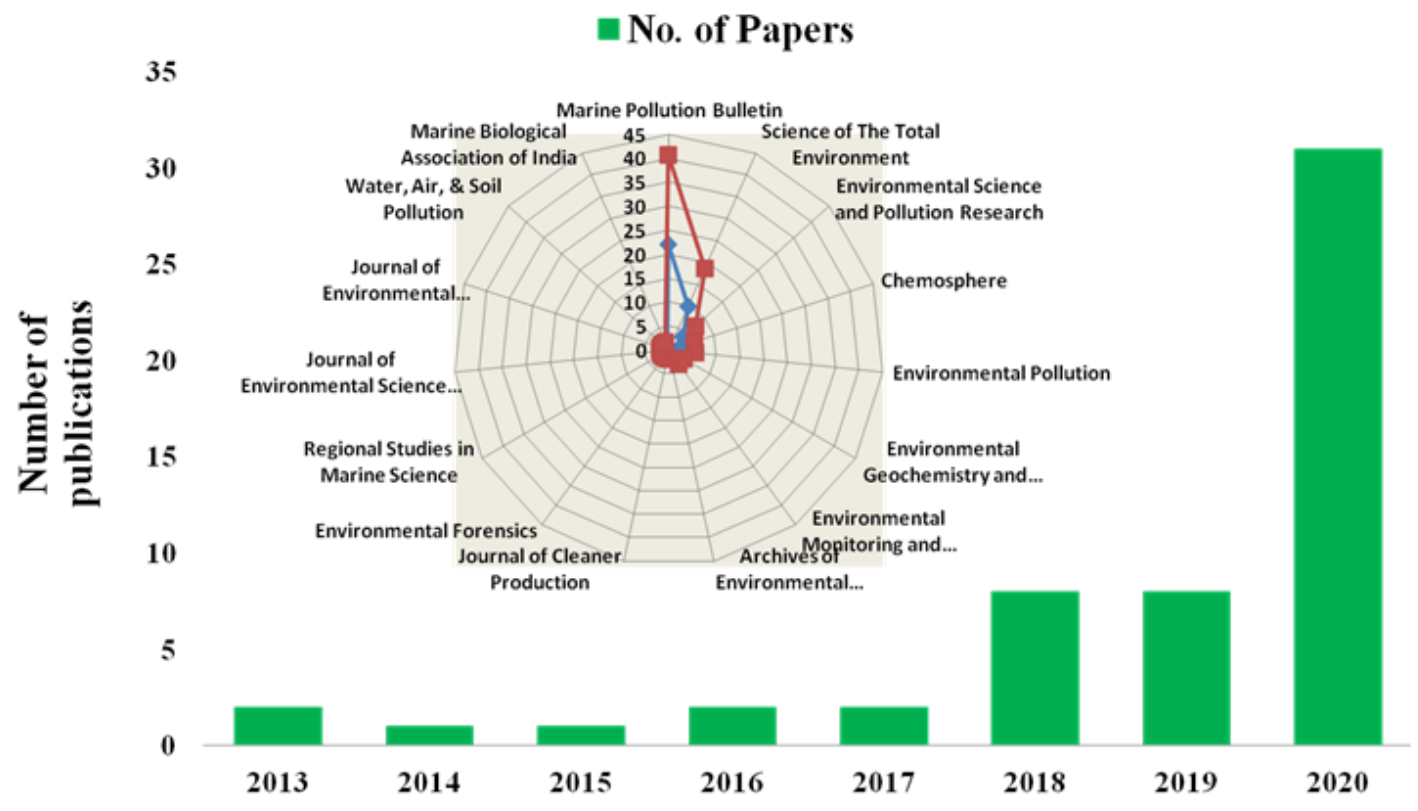

Figure 1

No. of papers published in journals categories using the database Web of Science (Clarivate Analyticals ${ }^{\circledR}$ ) regarding MPs research in India

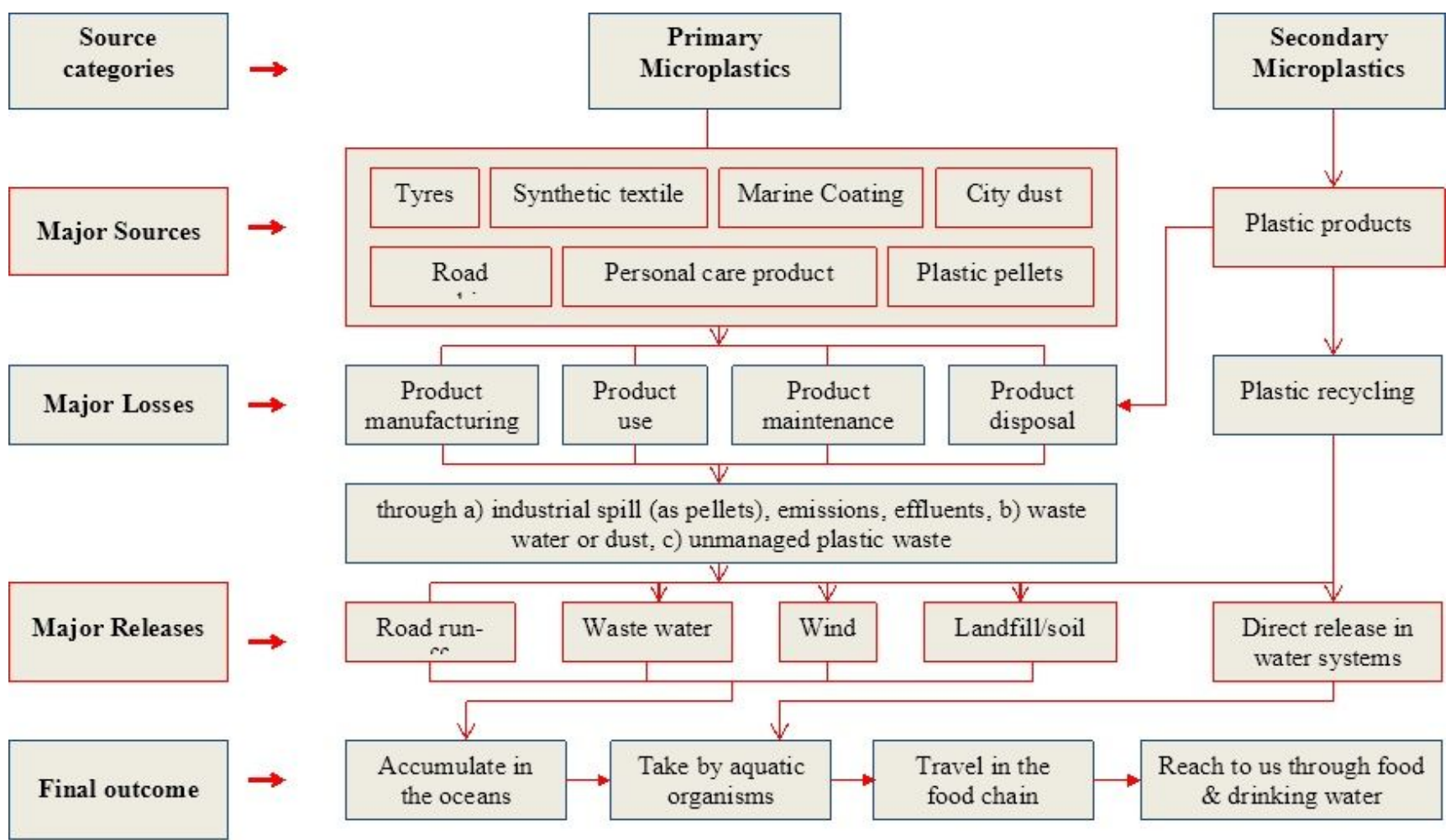

Figure 2

Sources of Microplastics (MPs) in the environment (IUCN 2017) 


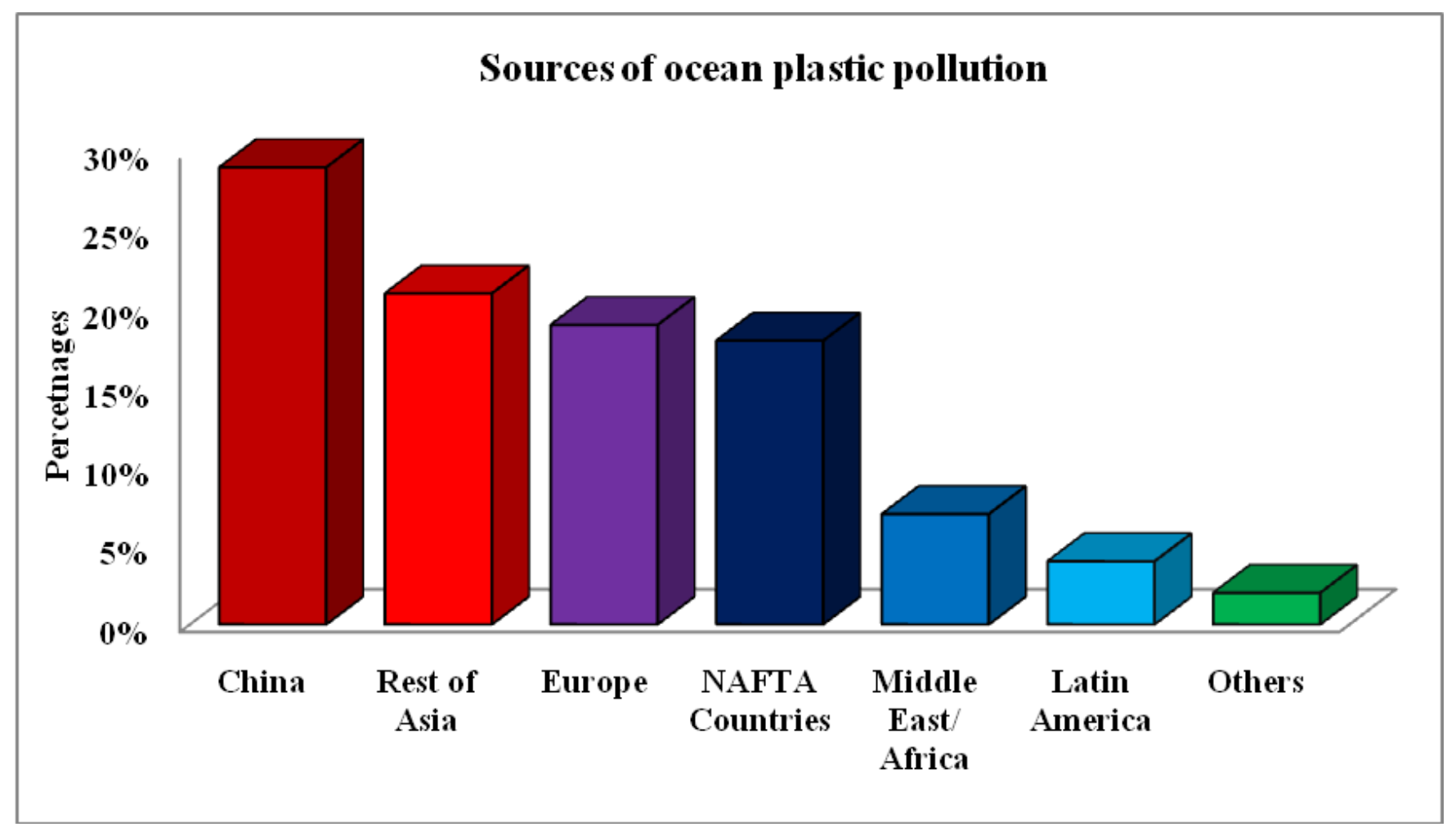

Figure 3

Sources of ocean plastic pollution 